\title{
Review
}

\section{Diabetic Retinopathy: From Animal Models to Cellular Signaling}

\author{
Priyamvada M. Pitale ${ }^{1(1)}$ and Marina S. Gorbatyuk $2, *$ (D) \\ 1 Department of Ophthalmology, Baylor College of Medicine, Houston, TX 77030, USA; \\ priyamvada.pitale@bcm.edu \\ 2 Department of Optometry and Vision Science, School of Optometry, University of Alabama at Birmingham, \\ Birmingham, AL 35294, USA \\ * Correspondence: mgortk@uab.edu; Tel.: +1-205-934-6762; Fax: +1-205-934-3425
}

Citation: Pitale, P.M.; Gorbatyuk, M.S. Diabetic Retinopathy: From Animal Models to Cellular Signaling. Int. J. Mol. Sci. 2022, 23, 1487 .

https://doi.org/10.3390/ ijms23031487

Academic Editor: Settimio Rossi

Received: 29 December 2021

Accepted: 26 January 2022

Published: 27 January 2022

Publisher's Note: MDPI stays neutral with regard to jurisdictional claims in published maps and institutional affiliations.

Copyright: (C) 2022 by the authors. Licensee MDPI, Basel, Switzerland. This article is an open access article distributed under the terms and conditions of the Creative Commons Attribution (CC BY) license (https:// creativecommons.org/licenses/by/ $4.0 /)$.

\begin{abstract}
Diabetic retinopathy (DR) is an ocular complication of diabetes mellitus (DM), a metabolic disorder characterized by elevation in blood glucose level. The pathogenesis of DR includes vascular, neuronal, and inflammatory components leading to activation of complex cellular molecular signaling. If untreated, the disease can culminate in vision loss that eventually leads to blindness. Animal models mimicking different aspects of DM complications have been developed to study the development and progression of DR. Despite the significant contribution of the developed DR models to discovering the mechanisms of DR and the recent achievements in the research field, the sequence of cellular events in diabetic retinas is still under investigation. Partially, this is due to the complexity of molecular mechanisms, although the lack of availability of models that adequately mimic all the neurovascular pathobiological features observed in patients has also contributed to the delay in determining a precise molecular trigger. In this review, we provide an update on the status of animal models of DR to help investigators choose an appropriate system to validate their hypothesis. We also discuss the key cellular and physiological events of DR in these models.
\end{abstract}

Keywords: animal models of diabetes; diabetic retina; electrophysiology of diabetic retina; cellular signaling of diabetic retina; tribbles homolog 3 protein

\section{Introduction}

Diabetic retinopathy (DR) is known to be an eye complication of diabetes mellitus (DM). If untreated, it can threaten the vision of affected individuals. Current clinical trials using in vivo imaging techniques have reported dramatic retinal morphological changes associated with diabetes. A study with 124 human subjects in the early stage of DR reported a decrease in the thickness of the nerve fiber layer (NFL) with no effects to the outer neural layer (ONL) of the retina, measured by spectral domain optical coherence tomography (SD-OCT) [1]. Electroretinographic changes have also confirmed retinal dysfunction in patients with severe ocular diabetic complications [2,3]. Furthermore, changes in retinal hemodynamics have also been reported in patients with early DM [4]. Currently, DR is recognized as a progressive neuro-vascular complication with neuronal dysfunction proceeding to microvascular damage [5]. The early stage of the disease is known as non-proliferative diabetic retinopathy (NPDR); it ranges from mild (microaneurysms) to severe (decrease in the blood flow due to blockade in a larger section of retinal blood vessels). Proliferative diabetic retinopathy (PDR), an advanced stage in which blood vessels grow in the retina, often leads to a reduced field of vision and blindness. While clinical trials concentrate on risk factors, early detection, and evaluations of the progression of DR in vivo, access to human donor eye tissue provides a great opportunity to study early molecular changes in the diabetic retina to further understand pathological markers. Multiple studies with postmortem donor eyes have reported glial cell dysfunction as a primary change in the diabetic retina. Thus, a recent study with postmortem diabetic ocular tissue that employed an immunolabelling technique to detect carbonic anhydrase (II) and 
glial fibrillary acidic protein (GFAP) identified the occurrence of Müller cell reactivation in the human diabetic retina [6,7]. The authors discovered that the Müller cells migrated in the pre-retinal membranes and overexpressed GFAP in the diabetic donor eyes.

In addition to structural and morphological alterations, molecular changes occurring in diabetic retinas have also been reported. Thus, studies on post-mortem diabetic eyes have shown the elevation of inflammatory markers; an increase in pro-death caspase-3, Fas, and Bax in the retinal ganglion cells (RGC); and GFAP in the retina [8-10]. Several studies on vitreous extracted from patients demonstrated that levels of interleukin-8, monocyte chemotactic protein-1, macrophage-colony stimulating factor, platelet-derived growth factor (PDGF), and vascular endothelial growth factor (VEGF) are elevated compared with non-diabetic individuals [11-14]. In addition, extracellular matrix proteins and an elevated expression of genes associated with angiogenesis and apoptosis were identified in fibrovascular membranes extracted from PDR patients during vitrectomy [15]. These analyses have also helped to identify potential therapeutic targets. Thus, it has been confirmed that VEGF plays an important role in the development of aberrant neovascularization in diabetic retinas and that VEGF is a biomarker of microangiopathy in PDR [16]. In addition to VEGF, increases in the number of apoptotic cells measured by a terminal deoxynucleotidyl transferase-mediated dUTP nick end labeling (TUNEL) assay, as well as pericyte and endothelial cell loss, were reported in the retinas of patients with diabetic microvascular complications [17]. Although studies with human donor tissues are an excellent asset for improving our understanding of the molecular signaling contributing to DR pathobiology, they cannot provide a complete picture of the mechanism of the development of DR. Moreover, human donor tissues may not be readily available. The use of genetic animal models addresses these limitations, and they provide an excellent approach to developing a comprehensive understanding of the cellular pathways associated with DR. While the choice of the appropriate animal model that mimics all aspects of human DR pathology is challenging, several models can capture key cellular and physiological events of diabetic retinopathy in humans. Therefore, in this literature review, we summarize the current status of the development of animal models used in research focusing on diabetic retinopathy.

\section{Experimental Diabetic Retinopathy}

One of the key regulators of homeostatic balance within the glucose metabolism in the body is insulin, which is produced by the beta cells of the pancreas. The insulin receptorsignaling pathway facilitates the entry of glucose into the cells through the activation of the protein kinase B (AKT)-mediated glucose transporter (GLUT1). In humans, fasting blood glucose level (BGL) is maintained in the range of $92-126 \mathrm{mg} / \mathrm{dL}$, while the postprandial blood glucose level is in the range of $97-140 \mathrm{mg} / \mathrm{dL}$. It is well accepted that under fasting and postprandial conditions, BGL levels above $126 \mathrm{mg} / \mathrm{dL}$ and $180 \mathrm{mg} / \mathrm{dL}$, respectively, are considered sustained hyperglycemia [18]. It is now accepted that hyperglycemia primarily drives NPDR, while sustained hypoxia results in the progression of PDR. Thus, based on these facts, animal models that mimic the pathophysiological events of DR were developed. These models differ by the approaches used to induce hyperglycemia (pharmaceutical agents, pancreatectomy, or genetically modified animals [19-23]), their classification in the phylogenic tree (rat, mouse, rabbit, monkey, zebrafish, dog, pig, cat, and tree shrew), the observed neuronal and vascular changes, and the activation of cellular signaling (Table 1). 
Table 1. Current animal models of diabetic retinopathy.

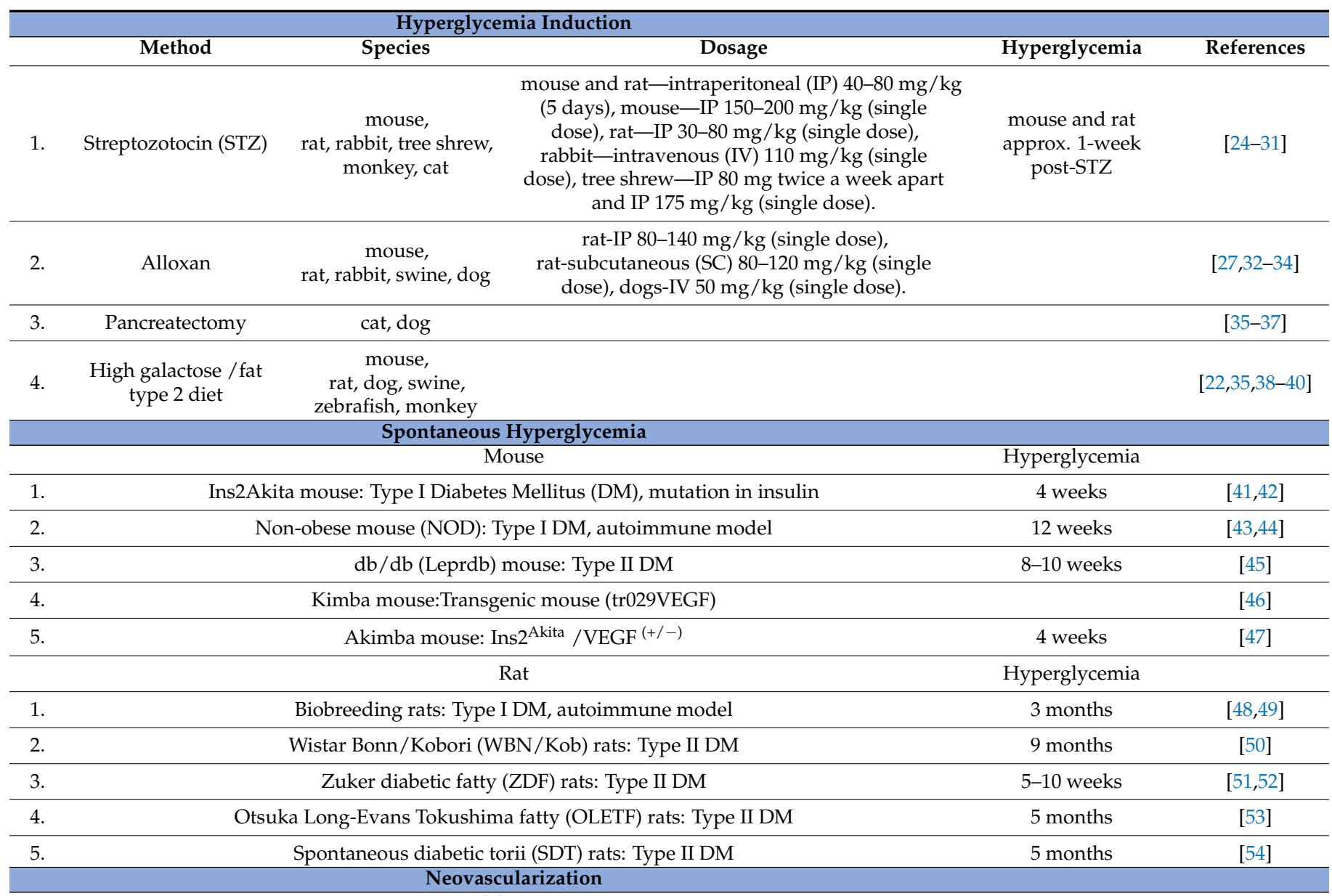

\begin{tabular}{|c|c|c|}
\hline 1. & Oxygen induced retinopathy (OIR) & [55] \\
\hline 2. & Kimba mouse & [46] \\
\hline \multirow[t]{2}{*}{3.} & Akimba mouse & [47] \\
\hline & Rat, Canine & \\
\hline \multirow[t]{2}{*}{1.} & Oxygen induced retinopathy (OIR) & [56-58] \\
\hline & Rabbit & \\
\hline \multirow[t]{2}{*}{1.} & Implantation of human recombinant VEGF in the vitreous & [59] \\
\hline & Zebrafish & \\
\hline \multirow[t]{2}{*}{1.} & Angiogenesis & {$[60,61]$} \\
\hline & Monkey & \\
\hline 1. & Implantation of human recombinant VEGF in the vitreous & [59] \\
\hline
\end{tabular}

\section{Induction of Hyperglycemia}

The pharmacological induction of hyperglycemia with streptozotocin (STZ) is the method used most frequently to develop a type 1 diabetes (T1D) model. Antibiotic STZ is produced by the bacterium Streptomyces achromogens and possesses a broad spectrum of antibacterial properties. Highly reactive methyl nitrosourea moiety is responsible for its cytotoxic effect, resulting in pancreatic $\beta$ cell necrosis, whereas glucose moiety facilitates its transports to the pancreatic $\beta$ cells. STZ acts via the GLUT2 receptors abundantly present on $\beta$ cell plasma membranes, which make pancreatic $\beta$ cells a specific target of STZ [19]. When administered either on five consecutive days or as a single dose, STZ leads to hyperglycemia [24]. For example, it has been reported that the STZ dosage for multiple 
intraperitoneal (IP) injections ranges from 40 to $80 \mathrm{mg} / \mathrm{kg}$ body weight (bw). A single dose administered within the range of $150-200 \mathrm{mg} / \mathrm{kg}$ bw in mice or 30-100 mg/kg bw in rats by IP injection also induces hyperglycemia [25-28]. In rabbits, intravenous injection (IV) with a dose of $110 \mathrm{mg} / \mathrm{kg}$ bw has been reported to trigger hyperglycemia [29]. In contrast, a single dose of $175 \mathrm{mg} / \mathrm{kg}$ is required to induce hyperglycemia in tree shrews [31]. Interestingly, the maintenance of fasting or non-fasting conditions before STZ injection does not change the postinduction hyperglycemic effect of STZ [62]. The hyperglycemia after STZ injection is usually seen within one to four weeks in most species. In some cases, insulin injections are necessary for hyperglycemic mice and rats to control the extreme fluctuations in the BGL, although they are not always necessary for STZ models [24]. An alternative to STZ, Alloxan, can also be used to induce hyperglycemia. This drug is commonly used in mice, rats, rabbits, and pigs. A pyrimidine derivative, alloxan, directly targets the beta cells of the pancreas, causing apoptosis by inhibiting the enzyme glucokinase and subsequently increasing the BGL due to lack of insulin production [21,35]. In rodent models, alloxaninduced hyperglycemia can be developed within one week of administration, while it takes less than a day in dogs [32].

Surgical and diet-induced hyperglycemia are alternative methods to induce experimental hyperglycemia. For example, in canine models, hyperglycemia develops three to four weeks after the surgery $[35,36]$. To accelerate the induction of hyperglycemia, the pharmacological approach can be combined with pancreatectomy. In addition to the above methods, dietary modifications can cause changes in the BGL. A high glucose/galactose diet is one such approach. Thus, Engerman and Kern used a high galactose diet to induce $\mathrm{DR}$ in dogs [22]. Other researchers have documented that diet-induced hyperglycemia leads to the development of DR in mice and rats [35]. However, it is worth mentioning that this approach can take years to develop DR in dogs and monkeys, while in rodents, the development of DR occurs much faster [22,38]. Genetic models of hyperglycemia were generated in rodents and zebrafish carrying gene mutations that lead to spontaneous hyperglycemia. These models are relatively easy to work with, and economical to develop and inbreed in controlled environments.

\section{Rodent Models of Diabetic Retinopathy}

Rat models. There are several spontaneous hyperglycemic rat models, including bio-breeding (BB) rats developing T1D, Wistar Bonn/Kobori (WBN/Kob), Zucker diabetic fatty (ZDF), Otsuka Long-Evans Tokushima fatty (OLETF), and spontaneous diabetic Torii (SDT) rats developing T2D. The BB rats manifest autoimmune DM and DR based on hyperglycemia registered at three months of age and retinal vascular changes at 8-11 months $[48,49]$. In WBN/Kob male rats, the onset of hyperglycemia occurs at nine months of age [50]. In contrast, ZDF rats develop hyperglycemia earlier, between 5 and 10 weeks of age. These animals are considered a non-insulin-dependent DM model. They are obese and carry a missense mutation known as $(f a / f a)$ mutation in the leptin receptor gene (Lepr). Originally, these rats were derived from the Zucker rats, which are an obesity disease model [51,52]. Male OLETF rats develop high BGL starting at five months [53]. In the SDT rat model, detection of glucose in the urine, which is a common sign of glucosuria and kidney damage in patients, was reported at 20 weeks of age in males and at 45 weeks of age in females [54].

Mouse models. Ins $2^{\text {Akita }}$, non-obese NOD, Kimba and Akimba mice developing T1D, and $\mathrm{db} / \mathrm{db}$ mice developing T2D are the most popular genetic models of DM. Ins2 ${ }^{\text {Akita }}$ mice have a point mutation in insulin2 (earlier reported locus Mody4), which causes abnormal insulin production by the pancreatic cells, leading to pancreatic cell death. The heterozygous Ins $2^{\text {Akita }}$ males are progressively hyperglycemic starting at four weeks of age, while females exhibit mild symptoms of DM. They have an average life span of 305 days and are primarily a model of early retinal complications caused by diabetes in humans [41,42]. Another model of T1D is the NOD mouse. These mice mimic human autoimmune insulindependent DM and exhibit CD4 and CD8 T cell-mediated autoimmune destruction of the 
pancreas $[43,44]$. Interestingly, there is a gender-based variability in the timeline for the development of hyperglycemia in these mice. Thus, $80 \%$ of the NOD females develop hyperglycemia at the age of 12 weeks, while males develop hyperglycemia later, at around 20 weeks of age [44]. The recently developed Kimba mice are a transgenic line (tr029VEGF) that mimics both NPDR and mild PDR [46]. This model is used for breeding with the Ins $2^{\text {Akita }}$ mice to generate an Ins $2^{\text {Akita }} / \mathrm{VEGF}^{+/-}$genotype and is known to be a new model for the comprehensive study of the mechanism of DR as a complication of T1D [47]. Another model, homozygous for the mutation $\left(\operatorname{Lepr}^{\mathrm{db}}\right) \mathrm{db} / \mathrm{db}$ mice, manifests signs of T2D and develops hyperglycemia at the age of 8-10 weeks (300 mg/dL B6.BKS(D)-Lepr ${ }^{d b} / \mathrm{J}$, stock\#000697) and at the age of 6 weeks (300 mg/dL, BKS.Cg-Dock7m $+/+$ Lepr ${ }^{d b} / \mathrm{J}$, stock\# 000642). These mice are widely used because, in addition to hyperglycemia, they model obesity and metabolic disorders [45].

\subsection{Pathological Signs in Rodent Models of Diabetic Retinopathy}

\subsubsection{Neovascularization and Microvascular Changes in Diabetic Rodents}

The most critical pathologic findings of PDR are neovascularization, hemorrhage, and fibro-vascular proliferation, leading to retinal traction and detachment and vitreous hemorrhage [63]. Oxygen-induced retinopathy (OIR) in rodents is an accurate and reproducible model of vascular proliferative changes in the retina [55]. Hypoxia-driven vascular proliferative changes seem to be similar to those seen in the retinopathy of prematurity, age-related macular degeneration, and diabetic retinopathy. OIR was developed in canine models for the first time in the early 1950s. In this model, Arnall Patz and colleagues investigated the effects of hyperoxia on retinal vessel development to study proliferative retinopathy [56,57]. To develop this model, one-day-old pups were exposed to hyperoxia for four consecutive days. In the early 1990s, this approach was introduced in rodents by Dr. Smith and her colleagues and has gained increasing popularity. In addition to OIR canines and rodents, aberrant angiogenesis has also been reported in zebrafish, rabbit, and monkey models.

The rodent OIR model is the most common approach to investigating the effect of hypoxia on the retina since it mimics the characteristics of human retinal proliferative changes $[55,58,64]$. Because retinal vasculature develops in the first two weeks of birth in rodents, researchers can leverage this opportunity to analyze the aberrant vascular development triggered by hypoxia. In this model, hypoxia is induced at postnatal day (P) 7 after the regression of hyaloid vessels to avoid the development of mixed hyaloidopathy. The rodent pups were then exposed to hyperoxia (75\% oxygen) for five consecutive days from P7 to P12 and then observed at room air from P13 to P17 [55]. The peak changes of neovascularization are usually observed at P17, and these are resolved by P25. The C57BL/ 6 mice or the Sprague Dawley (SD) rats are the common strains employed in this model due to their neovascular susceptibility to hypoxia $[58,64,65]$. The OIR mice developed irregular blood vessels and a reduction in the retinal inner and deep plexuses at P18, mimicking retinal proliferative events triggered by hypoxia in patients with diabetic complications [66]. Downie and colleagues reported an increase in extraretinal neovascularization and impaired pericyte distribution in the OIR SD rat retinas as early as P18 [67].

Genetically modified Akimba, Akita, and Kimba mice manifest vascular dysfunction. Akimba mice were specifically developed to study the microvascular changes of DR and showed these changes at the early age of eight weeks old [47]. Thus, at eight months of age, these mice developed neovascularization, retinal edema, and detachment that progressed further through 25 weeks of age [47]. In the Kimba mice, abnormal blood vessel development was seen as early as P28, while an increase in vascular permeability and adherent leukocytes was observed at six weeks of age. Additionally, loss of retinal capillaries, neovascularization, an increased avascular area, alteration in the vessel length, and pericyte loss were reported from nine weeks to the advanced age of 24 weeks $[46,68]$. Vascular dysfunction in Ins $2^{\text {Akita }}$ mice presents as an increase in leukocytosis at eight 
weeks, compromised vascular permeability at 12 weeks, microaneurysms at six months, and neovascularization at nine months of hyperglycemia [42,69].

STZ mice also show microvascular changes earlier in the course of diabetes compared to STZ-induced hyperglycemic rats. For example, vascular permeability detected by imaging the distribution of fluorescein-conjugated dextran is compromised in these animals as early as eight days post-STZ injection [70]. However, a decrease in arteriolar diameter and velocity were reported at four weeks and eight weeks post-STZ injection, respectively [26]. Later in the course of diabetes (six to nine months), the STZ-induced hyperglycemic mice manifested pericyte loss and developed acellular capillaries [71].

In albino Wistar-Kyoto rats, the blood retinal barrier (BRB) disruption occurs as early as two weeks post-STZ injection. Several studies reported early neovascular changes such as adherent leukocytosis and thickening of the basement membrane occurring at 8 and 12 weeks, respectively $[8,72,73]$. Gong et al. noted that neovascularization in STZ-injected $\mathrm{SD}$ rats can be observed at three to four months after induction of hyperglycemia. An increase in VEGFR1 and VEGFR2 expression levels was associated with neovascularization in STZ-induced rats [74]. Similar findings were observed in the Alloxan-induced diabetic rats; leukocytosis and neovascularization were reported at two and nine months after induction of hyperglycemia, respectively. At two months of sustained hyperglycemia, the authors observed pericyte loss, the formation of acellular capillaries, and basement membrane thickening $[75,76]$. In contrast, several other studies reported that BB rats with autoimmune T1D manifested these retinal changes as early as four months, while this model as well as genetic ZDF and obese OLETF rat models demonstrated BRB breakdown and pericyte loss at six to eight months $[48,49,51,53,77,78]$. Overall, these studies imply that the observed vascular dysfunction could vary in rat models of DR triggered by different insults. In addition to rats, hyperglycemia induced by a high-fat diet in $\mathrm{db} / \mathrm{db}$ mice with T2D also leads to an increase in vascular permeability and basement thickness at 13-14 weeks of hyperglycemia [79,80]. Moreover, these mice also demonstrate pericyte loss, blood retinal barrier disruption, and vascular leakage at 12 months of age [39].

Neuronal cell death and gliosis are observed in the diabetic retina of animals with diabetes. Thus, in hyperglycemic rats, GFAP activation has been reported. STZ injection results in an increase in GFAP immunoreactivity in the retina as early as six to seven weeks [81] and as late as $8-16$ weeks post-injection [81,82]. Retinal cell loss and functional changes have also been reported as early as two weeks and as late as 24 weeks post-STZ injection. Moreover, an increase in apoptotic cell death in the ONL, INL, and RGC layers resulting in a decrease in the total retinal thickness has been detected between 12 and 16 weeks postSTZ injections in rats $[82,83]$. In contrast, necrotic RGC death was reported at four weeks post-STZ treatment in rats [83]. These rats also manifested severe loss of photoreceptors at 12 and 24 weeks, [83] while in WBN/ Kob rat retinas, photoreceptor degeneration occurs earlier, at four weeks of age [50]. Our recent study also confirmed RGC function loss and cell death in STZ-induced hyperglycemic mice at 32 weeks post-injection [84] and tree shrews at 16 weeks post-injection [31]. In addition to retinal neurons, RPE degeneration was reported in diabetic retinas. Thus, in four-month-old diabetic BB rats, hyperglycemia induces RPE degeneration through focal necrosis [85]. In hyperglycemic OLETF rat retinas, the decrease in the thickness of the RPE layer along with a reduction in the INL and ONL thicknesses occurs later, at nine months after induction of hyperglycemia [53]. Much later, at 50 weeks post-hyperglycemia induction, retinal detachment and fibrous proliferation occurs in Torii (SDT) rats with spontaneous diabetes [54]. In other model of spontaneous diabetes, ZFD rats, extensive glial activation along with photoreceptor outer segment (POS) degeneration occurs in 32-week-old retinas [86].The latter agrees with multiple studies demonstrating the thinning of the INL and IPL in OIR rat pups at P18 $[67,84,87,88]$. In addition, the thinning of the inner limiting membrane (ILM) is observed in STZ-induced $\mathrm{SD}$ retinas [85].

In STZ-induced diabetic mice, RGC loss occurs between 6 and 12 weeks [89]. RGC death occurs through apoptosis. The number of RGC apoptotic positive cells measured 
by TUNEL is $25 \%$ higher than that in control retinas [90]. These data are similar to our observation of about a 30\% RGC death with this model, [84] although another study reported that the RGC density across the retina varies at 20 weeks post-STZ treatment [91]. A few studies with Ins $2^{\text {Akita }}$ mice detected early cone photoreceptor cell loss at three months. The authors observed a significant reduction in the IPL and INL thicknesses along with a diminishing number of RGCs at 22 weeks and 36 weeks of hyperglycemia [42,92]. Similarly, the OCT analysis of 16- and 28-week-old diabetic $\mathrm{db} / \mathrm{db}$ mice retinas showed thinning in the NFL and RGC layer at a rate of $0.104 \mu \mathrm{m}$ per week, resulting in a reduction of the total retinal thickness by 28 weeks $[91,93]$. The 28 -week-old diabetic $\mathrm{db} / \mathrm{db}$ mice also showed TUNEL positive photoreceptor cells and reduction in the ONL thickness. STZ-induced hyperglycemia in mice also leads to GFAP overexpression in retinal astrocytes at five weeks post-STZ treatment, while Müller cell gliosis are not seen even after 15 months of DM [71,94]. In contrast, the OIR mice demonstrated a reduction in the total retinal, INL, and IPL thicknesses, as well as distorted photoreceptor OS, neuronal loss, hyperactivity of Müller cells, and microglial activation at P18 [66]. Our experiments with OIR pups confirmed these findings [84].

\subsubsection{The Detection of Functional Changes of the Neural Retina in Diabetic Rodents}

Several studies with diabetic rats have reported ERG findings. First, there is a delay in the implicit time detected at four to seven weeks post-STZ. Second, a decrease in the a-wave of the scotopic ERG amplitude was detected at 10 weeks, while the b-wave amplitude was found to be reduced at 25 weeks after the induction of hyperglycemia [81,95-97]. Similar ERG findings were observed in SDT rats at 44 weeks post-STZ treatment $[98,99]$ and mice and rats with proliferative retinopathy at P18 $[66,67,87,88]$. In the STZ-treated mice, retinal functional test showed a decrease in the implicit time for OP at 4-6 weeks, reduction in the scotopic ERG a and b-wave amplitudes at six months and diminished photopic ERG negative amplitudes at eight months after the induction of hyperglycemia [84,100-102]. Moreover, $\mathrm{db} / \mathrm{db}\left(\right.$ Lepr $\left.^{\mathrm{db}}\right)$, Ins2 ${ }^{\text {Akita }}$, and high fat diet-induced diabetic mice manifested similar retinal function changes detected by ERG at 6, 9 and 12 months, respectively [39,69,92,103].

\subsection{Cellular Signaling Changes in the Diabetic Rodent Retina}

\subsubsection{Insulin Signaling in the Diabetic Retina}

Basal insulin receptor (IR) signaling has been extensively studied in the STZ-induced diabetic SD rat retina. It has been observed that the phosphorylation of insulin receptor (IR) in hyperglycemic retinas remained unchanged up to eight weeks post-injection, whereas PI3K activity was reduced by $25 \%$ compared to the controls. At 12 weeks postSTZ injection, both kinase activity and auto-phosphorylation of the IR were significantly decreased, suggesting that the basal IR activity is diminished in the diabetic retina. It was also demonstrated that Akt1 kinase activity was significantly diminished at eight weeks post-STZ injection, suggesting compromised glucose flux [104]. Kondo and colleagues observed important differences in insulin signaling between STZ-induced hyperglycemic mice and $\mathrm{db} / \mathrm{db}$ mouse models developing DR. Specifically, IR expression and tyrosine phosphorylation were upregulated the first week post-STZ treatment in mouse retinas, but no changes were observed in 8- to 10 -week-old $\mathrm{db} / \mathrm{db}$ mice. Moreover, IRS-1 expression was unaltered, while IRS-2 expression was increased in both $\mathrm{db} / \mathrm{db}$ and STZ-induced diabetic mouse retinas. In contrast, a few studies have reported a reduction in IR phosphorylation and an increase in the activity of the protein tyrosine phosphatase-1B (PTP1B) in the rod's inner segments one-week post-STZ injection in mice [105]. An analysis of phosphorylated PTP1B in these mouse retinas point to PTP1B as a promising therapeutic target to delay neurodegeneration in diabetic retinas [106]. Reduced IR kinase activity at 12 weeks of hyperglycemia was also reported in a study with Ins $2^{\text {Akita }}$ mice [42]. The potential contribution of excess glucose to local impairment of retinal insulin receptors and AKT activity has been proposed [104]. Our recent study confirmed an excess of glucose in 
diabetic retinas [84]. Moreover, other studies have reported reduced AKT phosphorylation as an early event in diabetic retinas with T1D [104,107] and T2D [108,109].

\subsubsection{Unfolded Protein Response (UPR) and Inflammation in the Diabetic Retina}

Endoplasmic reticulum (ER) stress is one of the important features of the molecular pathobiology of the diabetic retina. Three independent UPR arms became activated during the ER stress response in diabetic retinas, including PKR-like ER kinase (PERK) and eukaryotic translation initiation factor $2 \alpha(\mathrm{eIF} 2 \alpha)$; inositol-requiring protein $1 \alpha(\mathrm{IRE} 1 \alpha)$-X-box binding protein 1 (XBP1); and activating transcription factor 6 (ATF6)[110]. Activation of PERK kinase signaling results in phosphorylation $(\mathrm{p})$ of eukaryotic translation initiation factor $2 \alpha(\mathrm{eIF} 2 \alpha)$, leading to global translational arrest and upregulation of activating transcriptional factor 4 (ATF4), C/ERB homologous protein (CHOP), and tribbles homolog 3 (TRIB3) proteins. The triggering of ATF6 is associated with its autophosphorylation, translocation to Golgi, and cleavage leading to active p-ATF6 transcriptional factor. After autophosphorylation, IRE $1 \alpha$, possessing both the RNAse and kinase activities, trims the $\mathrm{Xbp} 1$ transcriptional factor, leading to the formation of activated transcriptional factor, which controls a variety of gene expressions. Cellular stresses such as hypoxia and glucose imbalance can trigger UPR. ER stress markers are upregulated in diabetic rat retinas as early as eight weeks after the onset of diabetes induced by STZ in SD rats [111]. Apoptotic protein caspase 12, CHOP, and phosphorylated c-Jun N-terminal kinase 1 (MAPK) were dramatically upregulated in these retinas. In addition, the elevation of MAPK kinase was detected in RGCs [111]. However, the differences in the expression of the upstream and downstream mediators of PERK signaling, Grp78 and Atf4 genes, respectively, were not significant in this study. These findings suggest that AFT4 might not be the only signaling molecule responsible for the increased VEGF level in diabetic retinas [112]. Using immune-histochemical detection, the investigators reported the elevation of HIF-1 $\alpha$, ATF6, $\mathrm{XBP} 1$, and CHOP proteins in STZ-induced diabetic rat retinas at two and four months [82]. This elevation was accompanied by a decrease in the autophagy marker LC3B-II levels, indicating a potential reduction in autophagy in the diabetic retinas of mice with four months of hyperglycemia [82]. Pro-apoptotic BAX was detected in hyperglycemic ZFD rat retinas at six weeks of age [113].

Inducing diabetes and DR by STZ injection in mice, Chung et al. and Zhong et al. reported the activation of the ER stress response and pro-inflammatory signaling $[114,115]$. They found that the diabetic mouse retinas manifest increased expression of GRP78, pPERK, CHOP, VEGF, and peIF2 $\alpha$ four weeks after STZ-induced hyperglycemia. Moreover, ATF4 deficiency resulted in altered inflammatory gene expression [115]. In addition to UPR markers, the above-mentioned study reported that MCP-1 and TNF- $\alpha$ expression simultaneously increased in diabetic retinas during the four-week period [114]. Interestingly, this study also highlighted that UPR signaling could be resolved later in diabetic mouse retinas, at six weeks post-STZ injection. In contrast, genetically modified Akita mice demonstrated an increase in p-elF2 $\alpha$ and GRP78 proteins (PERK arm) in addition to elevated IRE-1 and TNF $\alpha$ expression at 12 weeks of age [116,117]. Elevated levels of GRP78, ATF4, and peIF2 $\alpha$ were also found in the OIR model at P15 [117,118] and in 15-month-old $\mathrm{db} / \mathrm{db}$ (Lepr ${ }^{\mathrm{db}}$ ) mice [119]. Moreover, our study showed that limiting ATF4 expression in hypoxic retinas significantly reduced the degree of neovascularization in the OIR mouse retinas, [118] and the deficiency in ATF4 could reduce IL-1 $\beta$ in diseased retinas [120].

Our recent study with diabetic TRIB3 KO demonstrated that TRIB3 is a master regulator of insulin signaling and glucose metabolism in the retina (Figure 1). Thus, we revealed that TRIB3 is induced in diabetic retinas, leading to overexpression of HIF1a, GFAP, VEGF, GLUT1, and EGFR proteins. In turn, HIF1a regulates GLUT1 expression and, together with TRIB3, controls the uptake of glucose in the retina. Moreover, TRIB3 mediates the retinal ganglion cell fate decision, while TRIB3 KO results in neuronal survival and improvement of vascular health. 


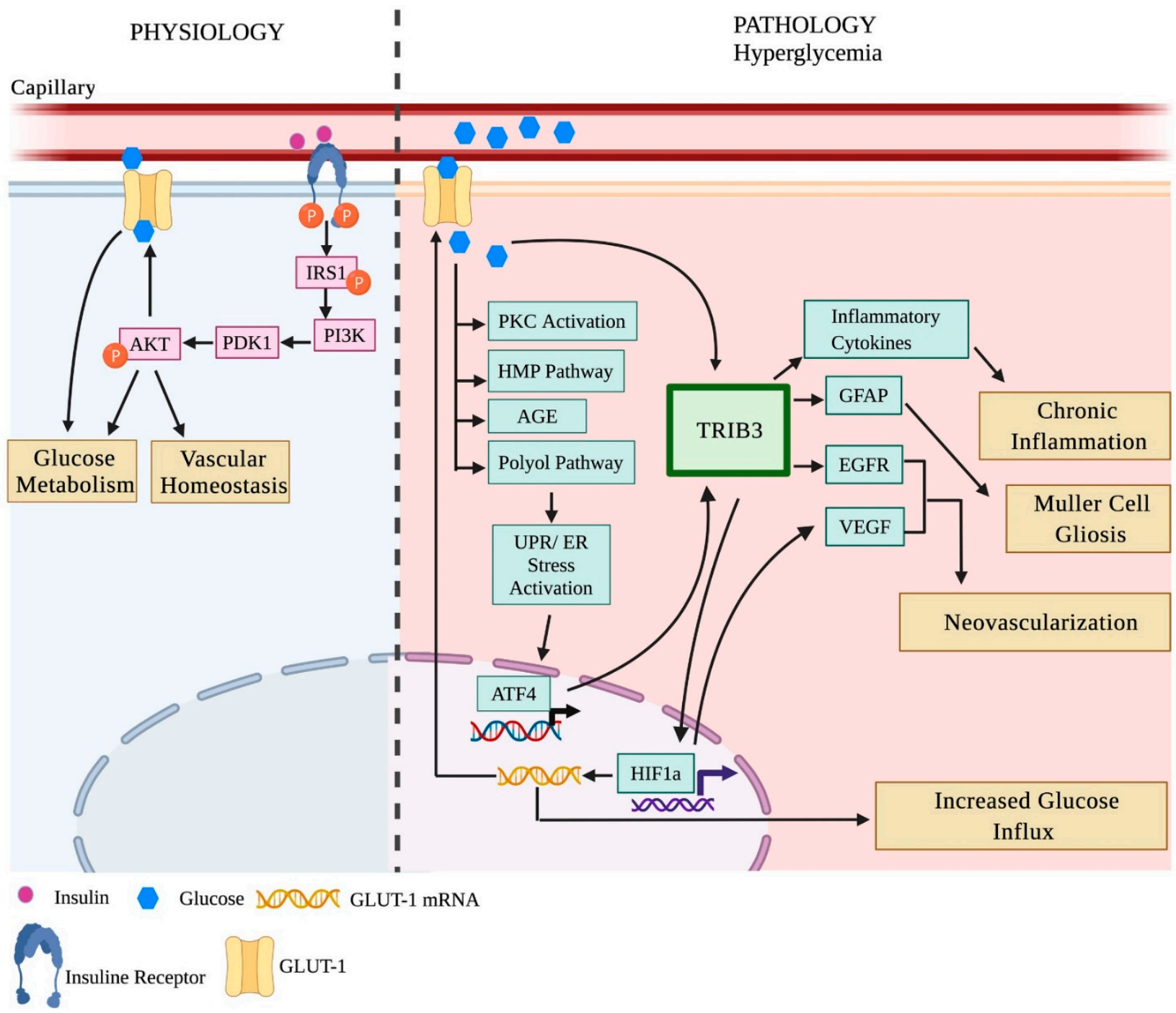

Figure 1. Tribbles homolog 3 (TRIB3) protein controls the development and progression of diabetic retinopathy. The PERK UPR marker TRIB3 is a known psuedokinase that binds and prevents AKT phosphorylation by PDK1. In addition, it controls the expression of HIF1 $\alpha$, EGFR, GFAP, and inflammatory cytokines in cells. In hyperglycemic retinas and retinas of mice with proliferative retinopathy, TRIB3 is significantly upregulated. This results in overexpression of HIF1 $\alpha$, EGFR, GFAP, and inflammatory cytokines (Icam1, Nf-kb1, Rc3h1, Zc3h12a, VEGF, COX2, and AIF1, [84]). In turn, overexpressed HIF1 $\alpha$ leads to GLUT1 activation and, together with TRIB3, increases the influx of glucose, which affects the overall glucose metabolism in diabetic retinas. Aberrant glucose flux and hyperglycemia in diabetic retinas are responsible for the activation of PKC, HMP, AGE, and polyol pathways, which eventually leads to chronic UPR activation. TRIB3-mediated proinflammatory cytokine expression results in chronic inflammation, GFAP increase leads to the retinal gliosis observed in proliferative retinas, and VEGF elevation triggers neovascularization in the late stages of DR. Image created by Biorender.com, (accessed on 30 May 2021).

Changes in inflammatory gene expression across varied rodent models of DR have also been reported. For example, six-week-old ZFD rat retinas manifest an increase in the levels of TNF- $\alpha$ and NF-kB [113]. Inflammatory proteins such as clusterin, the tissue inhibitor of metalloproteinase (TIMP)-1, $\beta-2$ microglobulin, and von Willebrand factor were overexpressed in the SD rat retinas at four weeks and, particularly, at three months post-STZ injection. In addition, the overexpression of fibroblast growth factor-2 (FGF2) was detected in the ONL of diabetic rat retinas at three months post-STZ. It is also worth 
mentioning that inflammatory changes are strain-dependent in diabetic rat models. For example, compared to Long-Evans and Brown Norway rats, SD rats show inflammatory changes more similar to those found in human diabetic retinopathy [121]. SD rat pups with OIR were also reported to overexpress inflammatory markers at P16 [58,64].

Overall, the above-mentioned studies emphasize that alterations in cellular molecular signaling often precede retinal pathophysiological events. These findings suggest that dysfunctional insulin signaling, ER stress response, and inflammation are involved in the pathological progression of DR and can be targeted to develop novel cellular therapies for DR (Table 2).

Table 2. Cellular signaling, loss of retinal function and integrity in rodent models of diabetic retinopathy.

\begin{tabular}{|c|c|c|c|c|}
\hline \multicolumn{5}{|c|}{ Molecular Signaling } \\
\hline & Model & Changes & $\begin{array}{c}\text { Duration of } \\
\text { Hyperglycemia }\end{array}$ & References \\
\hline \multirow{5}{*}{1.} & \multirow{5}{*}{ STZ Rat } & Elevated CHOP, Caspase 12, MAPK retinal cytokines & 8 weeks & \multirow{5}{*}[82,104,111,121]{} \\
\hline & & Reduced IR kinase activity & 8 weeks & \\
\hline & & Elevated retinal cytokines & 3 months & \\
\hline & & $\begin{array}{l}\text { Reduced IR kinase activity and autophosphorylation and } \\
\text { downregulation of IRS-2 \& PI3K }\end{array}$ & 3 months & \\
\hline & & Upregulation of HIF-A, ATF-6, XBP1 & 4 months & \\
\hline 2. & ZFD Rat & Elevated Bax, TNF- $\alpha$ and NF-kappaB & 6 weeks & {$[113]$} \\
\hline 3. & OIR Rat & Elevated VEGF, PDEG and TNF- $\alpha$ & P16 & {$[58,64]$} \\
\hline \multirow{4}{*}{4.} & \multirow{4}{*}{ STZ Mouse } & $\begin{array}{l}\text { Upregulation of GRP78, pPERK, CHOP, VEGF, pEIF2 } \alpha \text {, retinal } \\
\text { cytokine and TNF- } \alpha\end{array}$ & 4 weeks & \multirow{4}{*}[84,105,106,114-117]{} \\
\hline & & $\begin{array}{c}\text { Elevated IR expression and tyrosine phosphorylation; } \\
\text { upregulated IRS-2 and reduced PDK1/ AKT protein levels and } \\
\text { phosphorylation }\end{array}$ & 1 week & \\
\hline & & Reduced IR phosphorylation & 1 week & \\
\hline & & $\begin{array}{l}\text { Upregulation of TRIB3 and inflammatory cytokines (Icam1, } \\
\text { Nf-kb1, Rc3h1, Zc3h12a, VEGF, COX2, and AIF1) }\end{array}$ & 4 weeks & \\
\hline 5. & $\begin{array}{l}\text { Ins2Akita } \\
\text { Mouse }\end{array}$ & $\begin{array}{c}\text { VEGF and TNF- } \alpha \text { elevation, increased mRNA expression; } \\
\text { protein expression of GRP78 and elevated peIF2 } \alpha \text { and ATF4 and } \\
\text { reduced IR kinase activity }\end{array}$ & 12 weeks & {$[42,116,117]$} \\
\hline \multirow{2}{*}{6.} & \multirow{2}{*}{$\begin{array}{l}\text { Leprdb } \\
(\mathrm{db} / \mathrm{db}) \text { Mouse }\end{array}$} & $\begin{array}{l}\text { Increased IRS-2 expression and reduced PDK1/ AKT protein } \\
\text { levels and phosphorylation }\end{array}$ & 10 weeks & \multirow{2}{*}[116,119]{} \\
\hline & & $\begin{array}{c}\text { GFAP activation, increased expression of HIF-A, VEGF, GRP78, } \\
\text { p-IRE-1, CHOP, Casapase-3 and ATF4 }\end{array}$ & 15 months & \\
\hline \multicolumn{5}{|c|}{ Microangiopathy } \\
\hline & Model & Changes & $\begin{array}{c}\text { Duration of } \\
\text { Hyperglycemia }\end{array}$ & References \\
\hline \multirow{4}{*}{1.} & \multirow{4}{*}{ STZ Rat } & Blood retinal barrier disruption & 2 weeks & \multirow{4}{*}[8,72,74]{} \\
\hline & & Adherent leukocytes & 8 weeks & \\
\hline & & Thickened Basement Membrane (BM) & 12 weeks & \\
\hline & & Neovascularization & 3-4 months & \\
\hline \multirow{3}{*}{2.} & \multirow{3}{*}{ Alloxan Rat } & Leukocytosis & 2 months & \multirow{3}{*}[75,76]{} \\
\hline & & Neovascularization & 9 months & \\
\hline & & Pericyte loss, acellular capillaries, and BM thickening & 12 months & \\
\hline \multirow{3}{*}{3.} & \multirow{3}{*}{ BB Rat } & Basement membrane thickening & 4 months & \multirow{2}{*}[48,49,77]{} \\
\hline & & Blood retinal barrier breakdown & 6 months & \\
\hline & & Pericyte loss & 8 months & \\
\hline 4. & ZDF Rat & BM thickening, pericyte loss and acellular capillaries & 6 months & {$[51,52]$} \\
\hline 5. & OLETF Rat & BM thickening, pericyte loss and acellular capillaries & 9 months & {$[53,78]$} \\
\hline
\end{tabular}


Table 2. Cont.

\begin{tabular}{|c|c|c|c|c|}
\hline \multicolumn{5}{|c|}{ Molecular Signaling } \\
\hline & Model & Changes & $\begin{array}{c}\text { Duration of } \\
\text { Hyperglycemia }\end{array}$ & References \\
\hline 6. & OIR SD Rat & $\begin{array}{c}\text { Increased extra retinal neovascularization and impaired pericyte } \\
\text { distribution }\end{array}$ & P18 & [67] \\
\hline \multirow{4}{*}{7.} & \multirow{4}{*}{ STZ Mouse } & Increased vascular permeability & 8 days & \multirow{4}{*}[26,70,71,84]{} \\
\hline & & Decreased arteriolar diameter and velocity & 8 weeks & \\
\hline & & BM thickening & 4-15 months & \\
\hline & & Pericyte loss, acellular capillaries and pericyte ghost & 6-9 months & \\
\hline \multirow{4}{*}{8.} & \multirow{4}{*}{$\begin{array}{l}\text { Ins2Akita } \\
\text { Mouse }\end{array}$} & Leukocytosis & 8 weeks & \multirow{4}{*}[42,69]{} \\
\hline & & Increased vascular permeability & 12 weeks & \\
\hline & & $\begin{array}{c}\text { Blood vessels in the outer plexiform layer (OPL) and } \\
\text { microaneurysms }\end{array}$ & 6 months & \\
\hline & & Acellular capillaries, BM thickening and neovascularization. & 9 months & \\
\hline \multirow{4}{*}{9.} & \multirow{4}{*}{ Kimba Mouse } & Abnormal blood vessel development around photoreceptor & P28 & \multirow{4}{*}[46,68]{} \\
\hline & & Increased vascular permeability and adherent leukocytes & 6 weeks & \\
\hline & & $\begin{array}{l}\text { Loss of retinal capillaries, neovascularization, increased } \\
\text { avascular area and alteration in the vessel length }\end{array}$ & 9 weeks & \\
\hline & & Pericyte loss & 24 weeks & \\
\hline 10. & Akimba Mouse & $\begin{array}{c}\text { Microaneurysms, neovascularization, blood vessel constriction, } \\
\text { beading, vessel edema, capillary dropout, and new vessel } \\
\text { formation it the ONL }\end{array}$ & 8 weeks & [47] \\
\hline 11. & OIR Mouse & $\begin{array}{l}\text { Irregular blood vessel development and reduced inner retinal } \\
\text { plexus and deep plexus }\end{array}$ & P18 & [66] \\
\hline \multirow{3}{*}{12.} & \multirow{3}{*}{$\mathrm{Db} / \mathrm{db}$ Mouse } & Increased vascular permeability and BM thickening & 13-14 weeks & \multirow{3}{*}[79,80]{} \\
\hline & & Pericyte loss & 18 weeks & \\
\hline & & Acellular capillaries & 26 weeks & \\
\hline 13. & $\begin{array}{l}\text { High-fat diet } \\
\text { Mouse }\end{array}$ & $\begin{array}{l}\text { Pericyte loss, blood retinal barrier disruption and vascular } \\
\text { leakage }\end{array}$ & 12 months & [39] \\
\hline \multicolumn{5}{|c|}{ Retinal Integrity } \\
\hline & Model & Changes & $\begin{array}{c}\text { Duration of } \\
\text { Hyperglycemia }\end{array}$ & References \\
\hline \multirow{4}{*}{1.} & \multirow{4}{*}{ STZ Rat } & $\begin{array}{c}\text { Decreased pre- and post-synaptic photoreceptor ribbon } \\
\text { synapses }\end{array}$ & 4 weeks & \multirow{4}{*}{ [81-83] } \\
\hline & & Increased GFAP reactivity & 6-7 weeks & \\
\hline & & Loss of ONL, INL, GCL & 12-16 weeks & \\
\hline & & Severe photoreceptor cell loss & 24 weeks & \\
\hline \multirow{2}{*}{2.} & \multirow{2}{*}{ WBN/Kob Rat } & Photoreceptor degeneration & 4 weeks & \multirow{2}{*}{ [50] } \\
\hline & & Severe OS and ONL degeneration & 5-14 months & \\
\hline 3. & BB Rat & RPE degeneration & 4 months & [85] \\
\hline 4. & ZDF Rat & Decreased OS, damage to amacrine cells and RPE with gliosis & 32 weeks & [86] \\
\hline 5. & OLETF Rat & Decreased INL and photoreceptor cells & 9 months & [53] \\
\hline 6. & OIR Rat & $\begin{array}{c}\text { Reduction in OS, INL, IPL, total retinal thickness, astrocytes and } \\
\text { increased muller activity }\end{array}$ & P18 & {$[67,87]$} \\
\hline 7. & $\begin{array}{l}\text { High } \\
\text { galactose Rat }\end{array}$ & $\begin{array}{l}\text { Increased gliosis and reduced INL and } \\
\text { OPL }\end{array}$ & 28 months & [85] \\
\hline \multirow{5}{*}{8.} & \multirow{5}{*}{ STZ Mouse } & GFAP hyperactivity & 5 weeks & \multirow{5}{*}[71,84,89,91,94]{} \\
\hline & & Reduced ONL, INL thickness & 6-14 weeks & \\
\hline & & Total retinal thickness reduced & 20 weeks & \\
\hline & & No retinal cell loss and gliosis & $8-12$ months & \\
\hline & & Reduced RGCs & 8 months & \\
\hline
\end{tabular}


Table 2. Cont.

\begin{tabular}{|c|c|c|c|c|}
\hline \multicolumn{5}{|c|}{ Molecular Signaling } \\
\hline & Model & Changes & $\begin{array}{c}\text { Duration of } \\
\text { Hyperglycemia }\end{array}$ & References \\
\hline \multirow{4}{*}{9.} & \multirow{4}{*}{$\begin{array}{l}\text { Ins2Akita } \\
\text { Mouse }\end{array}$} & GFAP hyperactivity & 8 weeks & \multirow{4}{*}[42,92]{} \\
\hline & & Reduced IPL, INL and cone photoreceptors & 3 months & \\
\hline & & Reduced RGCs & 22 weeks & \\
\hline & & Decreased presynaptic and post-synaptic photoreceptor ribbons & 36 weeks & \\
\hline \multirow{2}{*}{10.} & \multirow{2}{*}{$\mathrm{db} / \mathrm{db}$ Mouse } & Reduced NFL and RGCs & $16-28$ weeks & \multirow{2}{*}[91,93]{} \\
\hline & & Reduced total retinal thickness & 28 weeks & \\
\hline 11. & Akimba Mouse & Photoreceptor cell death & 28 weeks & [47] \\
\hline 12. & OIR Mouse & $\begin{array}{c}\text { Total retinal thickness reduction, distorted photoreceptor OS, } \\
\text { neuronal loss, hyperactivity of Müller cells, microglial activation } \\
\text { and disrupted INL and IPL }\end{array}$ & P17-188 & {$[66,84]$} \\
\hline \multicolumn{5}{|c|}{ Retinal Electrophysiology } \\
\hline & Model & Changes & $\begin{array}{c}\text { Duration of } \\
\text { Hyperglycemia }\end{array}$ & References \\
\hline \multirow{3}{*}{1.} & \multirow{3}{*}{ STZ Rat } & Decrease in OP amplitude & 2-7 weeks & \multirow{3}{*}[81,98,99]{} \\
\hline & & Decrease in OP implicit time & 7 weeks & \\
\hline & & Decreased a- and b-wave amplitude & $\begin{array}{l}10-12 \text { weeks and } \\
\text { at } 44 \text { weeks }\end{array}$ & \\
\hline 2. & OIR Rat & Decreased a- and b-wave amplitude & P18 & {$[67,87,88]$} \\
\hline \multirow{3}{*}{3.} & \multirow{3}{*}{ STZ Mouse } & Reduced OP amplitude and implicit time & 4-6 weeks & \multirow{3}{*}[84,100-102]{} \\
\hline & & Reduced a- and b-wave amplitude & 6 months & \\
\hline & & Reduced PhNR amplitude & 8 months & \\
\hline 4. & $\begin{array}{l}\text { Ins2Akita } \\
\text { Mouse }\end{array}$ & Decreased OP amplitude, delay in the OP and decreased b-wave & 9 months & {$[42,92]$} \\
\hline 5. & $\mathrm{Db} / \mathrm{db}$ Mouse & $\begin{array}{l}\text { Delay in the b-wave, delay in the OP implicit time and } \\
\text { decreased amplitude of both photopic and scotopic b-wave }\end{array}$ & 16-24 weeks & {$[93,103]$} \\
\hline 6. & OIR Mouse & Significant decrease in the amplitude of a- and b-wave & P18 & {$[66]$} \\
\hline 7. & $\begin{array}{l}\text { High-fat diet } \\
\text { Mouse }\end{array}$ & Decreased OP amplitude & 12 months & [39] \\
\hline
\end{tabular}

\section{Non-Rodent Models of Diabetic Retinopathy}

The induction of hyperglycemia and the development of DR in dogs are very often achieved with a high-galactose diet. These treated dogs develop DR pathology changes similar to those found in patients with DR. It is worth mentioning that dogs with STZ-induced diabetes leading to DR were the first animal models to develop both NPDR and PDR [122]. In these dogs' retinas, the researchers detected an NPDR marker-pericyte loss-at nine months post-STZ injections. PDR complications such as hemorrhages, microaneurysms, basement membrane (BM) thickening, vitreous detachment, and neovascularization usually develop in this model later-within 28 to 68 months post-STZ treatment $[33,122]$.

Diabetic swine are another model of DR. The retinas of these animals have many similarities to human retinal tissues. Alloxan-induced T1D and diet-induced T2D pig models are frequently used models of DR. Alloxan treatment leads to the development of pericyte loss and BRB breakdown at 20 weeks after hyperglycemia in these pig's retinas [34]. In contrast, another study found that Alloxan induces Müller cell contraction-promoting activities affecting the vitreous at 30 days after induction of hyperglycemia in the swine model [123]. These findings suggest that the swine Müller cell contraction-promoting activity resulting in retinal detachment at the advanced stages of diabetes is similar to the changes seen in humans with DR. Another swine model is the combination model of DM and hypercholesteremia (DMHC). This model demonstrated increased BRB permeability, gliosis, microglial activation, and decreases retinal thickness at 24 weeks [124]. Kleinwort et al. 
reported intraretinal microvascular abnormalities and central retinal edema observed in a swine model of DR two years after the onset of hyperglycemia [125]. In four-month-old Ossabaw pigs fed with a western diet (high fat/high fructose corn syrup/high calories), Lim et al. reported development of chronic DM at 10 weeks. These animals also manifested retinal INL disruption, thickened BM, the formation of pericyte ghosts and acellular capillaries, and an increase in fibronectin expression at the age of six months [126].

The major drawback of DR studies on large animals is the delay in the development of histological features, making large animals less attractive species. Hatchell and colleagues were the first to develop the feline diabetic model using pancreatectomy and monitor them for nine years with regular checks for hyperglycemia every six months. They reported the presence of thickened BM at three months, microaneurysms at five years, and neovascularization around 6.5-8 years post-surgery in the diabetic cat retina [37]. Rhesus monkeys can develop DR through the implantation of $100 \mu \mathrm{g}$ of human recombinant VEGF [59] or through STZ-induced hyperglycemia. Retinal pathobiology associated with diabetes in these animals were observed after six years of hyperglycemia [127].

In addition to large diabetic models, small non-rodent animals manifest some features of DR after induction of hyperglycemia. For example, tree shrews are closely related to the primate animals that have cone-dominant retinas. Recently, our group validated tree shrews as a novel model of T1D manifesting some features of diabetic retinopathy [31]. Thus, we propose that diabetic tree shrews develop the retinal phenotypes of cone photoreceptor degeneration and RGC dysfunction, and mimic early stages of hyperglycemia-induced DR. Besides the fact that this model lays the groundwork for better understanding molecular pathophysiology of DR in humans, it can be an ideal bridge between the non-human primate and rodent models of diabetes; it simulates critical pathophysiological aspects of human DR and could be used to evaluate the effect of systemic pathogenesis of human diabetes, including the affected pancreas, liver, and kidneys on the development and progression of DR. A rabbit model was generated by STZ injections, resulting in the development of DR. Forty percent of diabetic rabbits with an average BGL of $200 \mathrm{mg} / \mathrm{dL}$ develop retinopathies after 135 days of initial STZ injections. Zebrafish von Hippel-Lindau (vhl) mutants and transgenic zebrafish (Fli-EGFP-Tg) exposed to hypoxic conditions also manifest features of DM $[60,61]$.

\subsection{Pathological Changes in Non-Rodent Animal Models of Diabetic Retinopathy}

After 135 days of initial STZ injections, hyperglycemic rabbits developed high-incident DR, classified as serious vasculopathy with retinal hemorrhages, vascular lesions, and venous thrombosis, as well as more severe DR, classified as PDR [29]. In another rabbit model of angiogenesis generated by the implantation of human recombinant VEGF at a dose of $30 \mu \mathrm{g}$, the vitreous showed abnormal tortuous blood vessels followed by vascular leakage at 14 days and neovascularization in the retina at 21 days of transplantation [59]. In zebrafish exposed to hypoxia, the retina demonstrated new sprouts in the optic capillary plexus and the formation of capillary tips 12 days post-exposure [60]. Aberrant blood vessel formation and an increase in VEGF mRNA expression was reported in a genetic fish model of DR, the mutant vhl zebrafish, at two days post-fertilization [61]. Zebrafish immersed in a high-glucose solution over a period of 30 days showed irreversible reduction in the IPL and INL of the retina and thickening of the blood vessels and their basement membrane [128,129]. The genetic manipulation and easily achievable hypoxic conditions with this model favors the use of zebrafish as a model for DR.

Primates closely mimic the disease pathology of the human retina. The implantation of human recombinant VEGF in the rhesus monkey resulted in an increase in vascular permeability, a breakdown of $\mathrm{BRB}$, and the tortuosity of the blood vessels in the vitreous at two to three weeks post-treatment [59]. STZ-induced diabetes leads to retinal pathology after six years of hyperglycemia in monkeys that include the presence of cotton-wool spots, macular atrophy, arteriolar occlusion, focal intraretinal capillary leakage, and capillary dilatation [127]. In addition to STZ-induced hyperglycemia, the markers of DR were 
also observed in mild hypertensive rhesus monkeys. Retinopathy in these animals was categorized into three stages: (1) microvascular abnormality with capillary dropout, (2) vascular leakage, intraretinal exudates, and cystoid degeneration with cotton wool spots, and (3) vascular occlusion and retinal atrophy [40]. In obese monkeys with T2D, these retinal findings develop slowly over a period of 1.25 to 15 years [130]. With aging, diabetic rhesus monkeys with T2D demonstrated a decline in retinal function measured by mERG recording; the a-wave of the scotopic ERG and the oscillatory potential were reduced in animals aged over five years [30]. Interestingly, the development of DR in monkeys could be achieved more quickly. For example, a recently developed diet-induced primate model of the marmoset monkey manifested development of DR within 2.5 years. Marmoset monkeys, which are smaller than rhesus macaques and easier to maintain, develop diabetesinduced retinal phenotype faster than other monkey models and thus present an excellent animal model of DR [38]. Table 3 summarizes major pathological changes observed in non-rodent models of diabetic retinopathy.

Table 3. Pathological changes in non-rodent models of diabetic retinopathy.

\begin{tabular}{|c|c|c|c|c|}
\hline & Model & Pathological Changes & Induction of DR & References \\
\hline \multirow{3}{*}{1.} & \multirow{3}{*}{$\begin{array}{l}\text { VEGF-induced angiogenesis } \\
\text { Rabbit }\end{array}$} & Tortuous blood vessels & \multirow{2}{*}{2 weeks } & \multirow{3}{*}{ [59] } \\
\hline & & Vascular leakage & & \\
\hline & & Neovascularization & 3 weeks & \\
\hline \multirow{2}{*}{2.} & \multirow{2}{*}{ Alloxan Rabbit } & Increase in the oxidated proteins and lipids & \multirow{2}{*}{6 weeks } & \multirow{2}{*}[132]{} \\
\hline & & Decline in p-PI3K/PI3K, p-AKT/AKT and p-GSK3/GSK3 ratios & & \\
\hline \multirow{2}{*}{3.} & \multirow{2}{*}{ STZ Rabbit } & Retinal hemorrhages and venous thrombosis & \multirow{2}{*}{19 weeks } & \multirow{2}{*}{ [29] } \\
\hline & & Vascular lesions & & \\
\hline \multirow{3}{*}{4.} & \multirow{3}{*}{$\begin{array}{c}\text { Hypoxic } \\
\text { Zebrafish/vhl-mutant } \\
\text { Zebrafish }\end{array}$} & Aberrant blood vessel formation & $\begin{array}{l}\text { 2-days-post-fertilization } \\
\text { (dpf) }\end{array}$ & \multirow{3}{*}[60,61]{} \\
\hline & & Formation of capillary tips and sprouts in optic capillary plexus & $12 \mathrm{dpf}$ & \\
\hline & & Increased mRNA VEGF & & \\
\hline \multirow{4}{*}{5 . } & \multirow{4}{*}{ Hyperglycemic Zebrafish } & Increased Vegf, Il-6, Il- $1 \beta$, Stat 3 , and $\operatorname{Tnf} \alpha$ mRNA expression & $3-6 \mathrm{dpf}$ & [131] \\
\hline & & Reduction in the IPL and INL & \multirow{3}{*}{$30 \mathrm{dpf}$} & \multirow{3}{*}[128,129]{} \\
\hline & & Thickening of the blood vessels & & \\
\hline & & BM thickening & & \\
\hline \multirow{3}{*}{6.} & \multirow{3}{*}{$\begin{array}{l}\text { VEGF induced } \\
\text { angiogenesis-Primate }\end{array}$} & Vascular permeability & \multirow{3}{*}{ 2-3 weeks } & \multirow{3}{*}{ [59] } \\
\hline & & Breakdown of BRB & & \\
\hline & & Tortuosity of the blood vessels & & \\
\hline \multirow{5}{*}{7.} & \multirow{5}{*}{ STZ Primate } & Presence of cotton-wool spots & \multirow{5}{*}{6 years } & \multirow{5}{*}{ [127] } \\
\hline & & Macular atrophy & & \\
\hline & & Arteriolar occlusion & & \\
\hline & & Focal intraretinal capillary leakage & & \\
\hline & & Capillary dilatation & & \\
\hline \multirow{2}{*}{8.} & \multirow{2}{*}{ Obese Primate } & Decreased a-wave of the scotopic ERG & \multirow{2}{*}{5 years } & \multirow{2}{*}{ [130] } \\
\hline & & Reduced oscillatory potential & & \\
\hline \multirow{4}{*}{9.} & & $\begin{array}{l}\text { Excess vascular permeability. } \\
\text { Increased acellular capillaries and pericyte loss }\end{array}$ & & \\
\hline & Diet-induced DR Marmoset & BM thickening and vessel tortuosity & 2.5 years & {$[38]$} \\
\hline & & Thickening of the retinal foveal & & \\
\hline & & Microaneurysms & & \\
\hline
\end{tabular}


Table 3. Cont.

\begin{tabular}{|c|c|c|c|c|}
\hline & Model & Pathological Changes & Induction of DR & References \\
\hline \multirow{4}{*}{10.} & \multirow{4}{*}{ STZ Tree shrew } & Upregulation of TRIB3 & \multirow{4}{*}{16 weeks } & \multirow{4}{*}{ [31] } \\
\hline & & Upregulation of $\mathrm{p}-\mathrm{AKT} / \mathrm{AKT} \rightarrow \mathrm{p}-\mathrm{mTOR} / \mathrm{mTOR}$ & & \\
\hline & & Increased IRS & & \\
\hline & & RGC function loss and cell death & & \\
\hline \multirow{5}{*}{11.} & \multirow{5}{*}{ STZ Dog } & Pericyte loss & 9 months & \multirow{5}{*}[33,122]{} \\
\hline & & Hemorrhages and microaneurysms & \multirow{4}{*}{$28-68$ months } & \\
\hline & & BM thickening & & \\
\hline & & Vitreous detachment & & \\
\hline & & Neovascularization & & \\
\hline \multirow{3}{*}{12.} & \multirow{3}{*}{ Pancreatectomy Cat } & BM thickening & 3 months & \multirow{3}{*}{ [37] } \\
\hline & & Microaneurysm & 5 years & \\
\hline & & Neovascularization & $6.5-8$ years & \\
\hline 13. & Alloxan Pig & Pericyte loss and BRB breakdown & 20 weeks & [34] \\
\hline \multirow{3}{*}{14.} & \multirow{3}{*}{ STZ Pig } & BRB permeability & \multirow{3}{*}{24 weeks } & \multirow{3}{*}{ [124] } \\
\hline & & Gliosis and microglial activation & & \\
\hline & & Decrease in retinal thickness & & \\
\hline \multirow{4}{*}{15.} & \multirow{4}{*}{ High-fat diet Pig } & INL disruption & \multirow{4}{*}{6 months } & \multirow{4}{*}{ [126] } \\
\hline & & BM thickening & & \\
\hline & & Pericyte ghosts and acellular capillaries & & \\
\hline & & Increase in fibronectin expression & & \\
\hline
\end{tabular}

\subsection{Cellular Signaling Changes in the Diabetic Retina of Non-Rodent Models}

It is worth mentioning that the reports on the alteration of cellular signaling in nonrodent diabetic retinas are scarce in the PubMed system. Thus, it has been demonstrated that high glucose triggers the Vegf, Il-6, Il-1 $\beta$, Stat3, and Tnfo mRNA expression in Zebrafish retinas that were associated with an increase in $\mathrm{TUNEL}^{+}$cells in the retina. [131] Rabbits with T1D mellitus induced by alloxan injection and analyzed at six weeks after induction of diabetes manifest an increase in the oxidated proteins and lipids, a decrease in enzymatic activity (catalase, glutathione peroxidase and superoxide dismutase), and a decline in p-PI3K/PI3K, p-AKT/AKT and p-GSK3/GSK3 ratios [132]. In contrast, our study with diabetic tree shrews demonstrated that diabetic retinas experience the elevation of TRIB3 and $\mathrm{p}-\mathrm{AKT} / \mathrm{AKT} \rightarrow \mathrm{p}-\mathrm{mTOR} / \mathrm{mTOR}$ signaling, whereas the IRS level at 16 weeks of hyperglycemia was reduced [31]. Although retinal vascular leakage was not observed in these animals, the retina VEGF level was slightly increased, suggesting that vascular abnormalities could be detected later in diabetic tree shrews.

\section{The Limitation of Animal Models of Diabetic Retinopathy}

In this review, we highlighted the differences between various models of DR (Figure 2). The cellular molecular pathology associated with the long-term development of diabetes seems not to be uniform across different research groups. For example, Martin and colleagues reported retinal cell loss in STZ-treated mouse retinas, while Feit-Leichman and co-authors observed no changes in the retinas of these diabetic mice [71,90]. These findings could be attributed to the different strains used for the development of STZ-induced hyperglycemia. In addition, although high BGL is consistent across the studies, investigating groups may use additional injections of STZ to maintain high BGL in experimental animals. Interestingly, STZ-induced hyperglycemia is gender dependent. Male mice are more prone to STZ-induced pancreatic damage compared to females because the effect of STZ is inhibited by the female hormone estrogen [133]. Saadane and colleagues recently reported that increasing the STZ dose by almost $36 \%$ yields hyperglycemia levels and subsequent 
retinal pathological changes in females similar to those found in males [134]. Despite these limitations, the chemical induction of hyperglycemia is still the fastest method to induce diabetes compared with spontaneous T1D and T2D models. The OIR mouse model is a particularly strain-dependent model, and the maintenance of genetic background in experimental mice is of the utmost importance [65]. The rodent models, in comparison to large mammals, provide better accessibility to molecular changes and genetic manipulation, as well as a shorter time period for the development of diabetes and easier handling. The only advantage of using primates and other large animals is their close resemblance to human retinal physiology. Thus, choosing the appropriate animal model for DR research is a challenging process and requires careful evaluation.

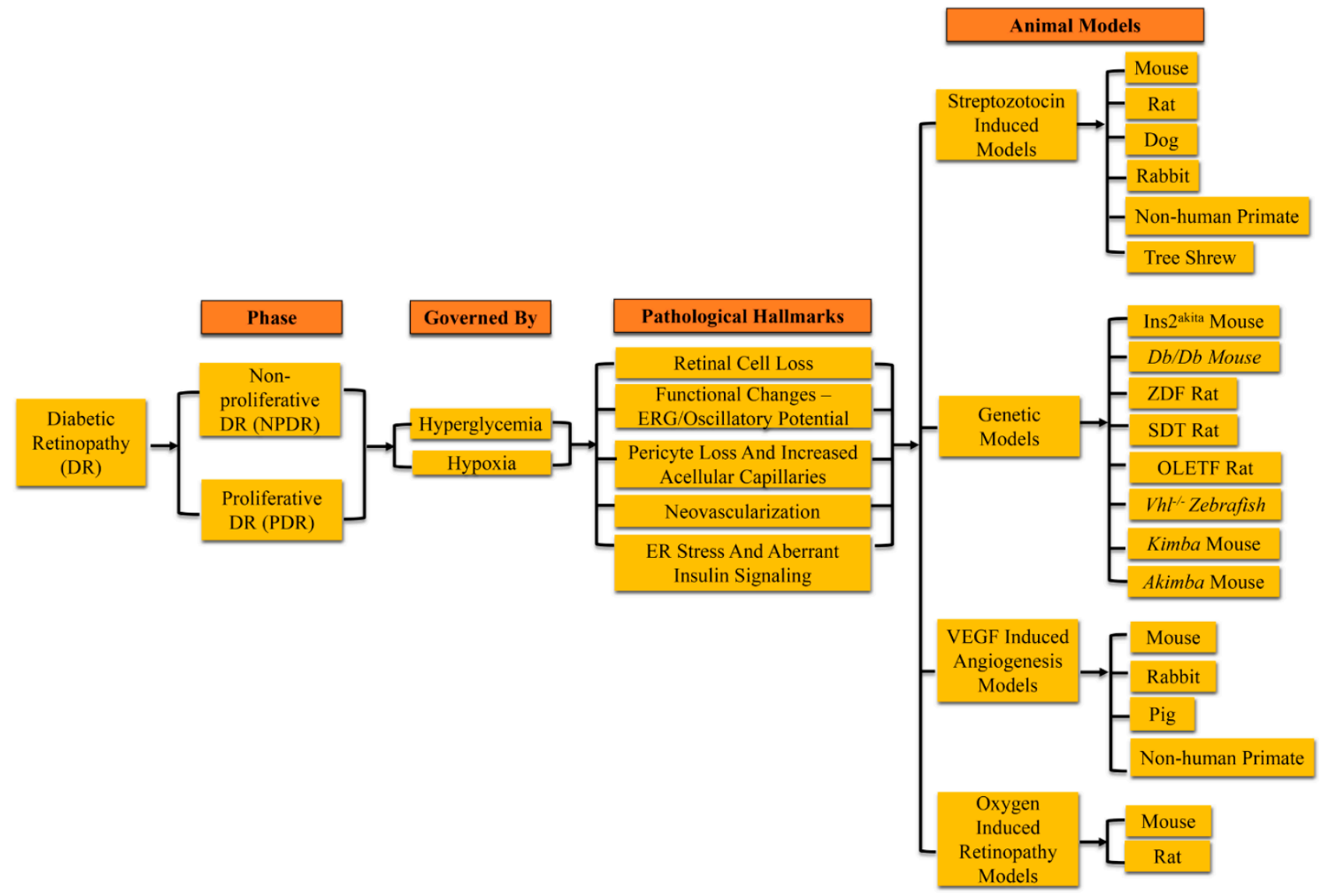

Figure 2. Animal models of diabetic retinopathy were developed to mimic non-proliferative and proliferative stages of diabetic retinopathy (DR). These models were created by inducing hyperglycemia or hypoxic conditions. Observed retinal pathophysiological features present neuronal function and cell loss in addition to vascular dysfunction. These models include rodents, cats, dogs, pigs, nonhuman primates, and zebra fish. They are genetically modified and/or pharmacologically-induced animal models of DR. (ERG-Electroretinogram; ER- Endoplasmic reticulum; ZDF- Zucker diabetic fatty; OLETF- Otsuka Long-Evans Tokushima fatty; vhl- von Hippel-Lindau).

\section{Conclusions}

The current review emphasizes several critical factors that should be considered before making a decision on a suitable animal model of DR. In particular, factors such as the duration of the study, the methods of induction of hyperglycemia, and the established molecular and pathophysiological markers of diabetic retinopathy should be considered carefully. Because not all animal models accurately mimic the diabetic human retinal pathology, it is important to evaluate the strengths and weaknesses of each animal model to properly design research experiments. 


\begin{abstract}
Author Contributions: All the authors contributed to the development of this review article. Conceptualization, P.M.P.; writing—original draft preparation, P.M.P.; writing—review and editing, P.M.P. and M.S.G.; supervision, M.S.G.; funding acquisition, M.S.G. All authors have read and agreed to the published version of the manuscript.
\end{abstract}

Funding: This work was supported by the NEI R01EY027763 and R21EY031103.

Institutional Review Board Statement: All experiments cited in this review were approved by the UAB Institutional Animal Care and Use Committee and adhered to all standards set forth in the ARVO Statement for the Use of Animals in Ophthalmic and Vision Research (Protocols 09793 and 21341).

Informed Consent Statement: Not applicable.

Data Availability Statement: Not applicable.

Conflicts of Interest: The authors declare that there is no conflict of interest.

\title{
References
}

1. Vujosevic, S.; Midena, E. Retinal layers changes in human preclinical and early clinical diabetic retinopathy support early retinal neuronal and Muller cells alterations. J. Diabetes Res. 2013, 2013, 905058. [CrossRef] [PubMed]

2. Baget-Bernaldiz, M.; Romero-Aroca, P.; Bautista-Perez, A.; Mercado, J. Multifocal electroretinography changes at the 1-year follow-up in a cohort of diabetic macular edema patients treated with ranibizumab. Doc. Ophthalmol. 2017, 135, 85-96. [CrossRef] [PubMed]

3. Tehrani, N.M.; Riazi-Esfahani, H.; Jafarzadehpur, E.; Mirzajani, A.; Talebi, H.; Amini, A.; Mazloumi, M.; Roohipoor, R.; RiaziEsfahani, M. Multifocal Electroretinogram in Diabetic Macular Edema; Correlation with Visual Acuity and Optical Coherence Tomography. J. Ophthalmic. Vis. Res. 2015, 10, 165-171. [CrossRef] [PubMed]

4. Grunwald, J.E.; DuPont, J.; Riva, C.E. Retinal haemodynamics in patients with early diabetes mellitus. Br. J. Ophthalmol. 1996, 80, 327-331. [CrossRef] [PubMed]

5. Sinclair, S.H.; Schwartz, S.S. Diabetic Retinopathy-An Underdiagnosed and Undertreated Inflammatory, Neuro-Vascular Complication of Diabetes. Front. Endocrinol. 2019, 10, 843. [CrossRef]

6. Nork, T.M.; Wallow, I.H.; Sramek, S.J.; Anderson, G. Muller's cell involvement in proliferative diabetic retinopathy. Arch. Ophthalmol. 1987, 105, 1424-1429. [CrossRef]

7. Mizutani, M.; Gerhardinger, C.; Lorenzi, M. Muller cell changes in human diabetic retinopathy. Diabetes 1998, 47, 445-449. [CrossRef]

8. Rungger-Brandle, E.; Dosso, A.A.; Leuenberger, P.M. Glial reactivity, an early feature of diabetic retinopathy. Investig. Ophthalmol. Vis. Sci. 2000, 41, 1971-1980.

9. Barber, A.J.; Antonetti, D.A.; Gardner, T.W. Altered expression of retinal occludin and glial fibrillary acidic protein in experimental diabetes. The Penn State Retina Research Group. Investig. Ophthalmol. Vis. Sci. 2000, 41, 3561-3568.

10. Abu-El-Asrar, A.M.; Dralands, L.; Missotten, L.; Al-Jadaan, I.A.; Geboes, K. Expression of apoptosis markers in the retinas of human subjects with diabetes. Investig. Ophthalmol. Vis. Sci. 2004, 45, 2760-2766. [CrossRef]

11. Muramatsu, D.; Wakabayashi, Y.; Usui, Y.; Okunuki, Y.; Kezuka, T.; Goto, H. Correlation of complement fragment C5a with inflammatory cytokines in the vitreous of patients with proliferative diabetic retinopathy. Graefe's Arch. Clin. Exp. Ophthalmol. 2013, 251, 15-17. [CrossRef] [PubMed]

12. Abu El-Asrar, A.M.; Struyf, S.; Kangave, D.; Geboes, K.; Van Damme, J. Chemokines in proliferative diabetic retinopathy and proliferative vitreoretinopathy. Eur. Cytokine Netw. 2006, 17, 155-165. [CrossRef] [PubMed]

13. Freyberger, H.; Brocker, M.; Yakut, H.; Hammer, J.; Effert, R.; Schifferdecker, E.; Schatz, H.; Derwahl, M. Increased levels of platelet-derived growth factor in vitreous fluid of patients with proliferative diabetic retinopathy. Exp. Clin. Endocrinol. Diabetes 2000, 108, 106-109. [CrossRef] [PubMed]

14. Elner, S.G.; Elner, V.M.; Jaffe, G.J.; Stuart, A.; Kunkel, S.L.; Strieter, R.M. Cytokines in proliferative diabetic retinopathy and proliferative vitreoretinopathy. Curr. Eye Res. 1995, 14, 1045-1053. [CrossRef] [PubMed]

15. Ishikawa, K.; Yoshida, S.; Kobayashi, Y.; Zhou, Y.; Nakama, T.; Nakao, S.; Sassa, Y.; Oshima, Y.; Niiro, H.; Akashi, K.; et al. Microarray analysis of gene expression in fibrovascular membranes excised from patients with proliferative diabetic retinopathy. Investig. Ophthalmol. Vis. Sci. 2015, 56, 932-946. [CrossRef] [PubMed]

16. Lutty, G.A.; McLeod, D.S.; Merges, C.; Diggs, A.; Plouet, J. Localization of vascular endothelial growth factor in human retina and choroid. Arch. Ophthalmol. 1996, 114, 971-977. [CrossRef]

17. Mizutani, M.; Kern, T.S.; Lorenzi, M. Accelerated death of retinal microvascular cells in human and experimental diabetic retinopathy. J. Clin. Investig. 1996, 97, 2883-2890. [CrossRef]

18. Giugliano, D.; Ceriello, A.; Esposito, K. Glucose metabolism and hyperglycemia. Am. J. Clin. Nutr. 2008, 87, 217S-222S. [CrossRef]

19. Eleazu, C.O.; Eleazu, K.C.; Chukwuma, S.; Essien, U.N. Review of the mechanism of cell death resulting from streptozotocin challenge in experimental animals, its practical use and potential risk to humans. J. Diabetes Metab. Disord. 2013, 12, 60. [CrossRef] 
20. Sakata, N.; Yoshimatsu, G.; Tsuchiya, H.; Egawa, S.; Unno, M. Animal models of diabetes mellitus for islet transplantation. Exp. Diabetes Res. 2012, 2012, 256707. [CrossRef]

21. McLetchie, N.G. Alloxan diabetes: A discovery, albeit a minor one. J. R. Coll. Physicians Edinb. 2002, 32, 134-142. [PubMed]

22. Engerman, R.L.; Kern, T.S. Experimental galactosemia produces diabetic-like retinopathy. Diabetes 1984, 33, 97-100. [CrossRef] [PubMed]

23. Rakieten, N.; Rakieten, M.L.; Nadkarni, M.V. Studies on the diabetogenic action of streptozotocin (NSC-37917). Cancer Chemother. Rep. 1963, 29, 91-98. [PubMed]

24. Lai, A.K.; Lo, A.C. Animal models of diabetic retinopathy: Summary and comparison. J. Diabetes Res. 2013, 2013,106594 [CrossRef]

25. Serra, A.M.; Waddell, J.; Manivannan, A.; Xu, H.; Cotter, M.; Forrester, J.V. CD11b+ bone marrow-derived monocytes are the major leukocyte subset responsible for retinal capillary leukostasis in experimental diabetes in mouse and express high levels of CCR5 in the circulation. Am. J. Pathol. 2012, 181, 719-727. [CrossRef]

26. Wright, W.S.; Harris, N.R. Ozagrel attenuates early streptozotocin-induced constriction of arterioles in the mouse retina. Exp. Eye Res. 2008, 86, 528-536. [CrossRef]

27. Mostafavinia, A.; Amini, A.; Ghorishi, S.K.; Pouriran, R.; Bayat, M. The effects of dosage and the routes of administrations of streptozotocin and alloxan on induction rate of type1 diabetes mellitus and mortality rate in rats. Lab. Anim. Res. 2016, 32, 160-165. [CrossRef]

28. Allen, R.S.; Hanif, A.M.; Gogniat, M.A.; Prall, B.C.; Haider, R.; Aung, M.H.; Prunty, M.C.; Mees, L.M.; Coulter, M.M.; Motz, C.T.; et al. TrkB signalling pathway mediates the protective effects of exercise in the diabetic rat retina. Eur. J. Neurosci. 2018, 47, 1254-1265. [CrossRef]

29. Drago, F.; La Manna, C.; Emmi, I.; Marino, A. Effects of sulfinpyrazone on retinal damage induced by experimental diabetes mellitus in rabbits. Pharmacol. Res. 1998, 38, 97-100. [CrossRef]

30. Johnson, M.A.; Lutty, G.A.; McLeod, D.S.; Otsuji, T.; Flower, R.W.; Sandagar, G.; Alexander, T.; Steidl, S.M.; Hansen, B.C. Ocular structure and function in an aged monkey with spontaneous diabetes mellitus. Exp. Eye Res. 2005, 80, 37-42. [CrossRef]

31. Gorbatyuk, O.S.; Pitale, P.M.; Saltykova, I.V.; Dorofeeva, I.B.; Zhylkibayev, A.A.; Athar, M.; Fuchs, P.A.; Samuels, B.C.; Gorbatyuk, M.S. A Novel Tree Shrew Model of Diabetic Retinopathy. Front. Endocrinol. 2021, 12, 799711. [CrossRef] [PubMed]

32. Black, H.E.; Rosenblum, I.Y.; Capen, C.C. Chemically induced (streptozotocin-alloxan) diabetes mellitus in the dog. Biochemical and ultrastructural studies. Am. J. Pathol. 1980, 98, 295-310.

33. Cusick, M.; Chew, E.Y.; Ferris, F., 3rd; Cox, T.A.; Chan, C.C.; Kador, P.F. Effects of aldose reductase inhibitors and galactose withdrawal on fluorescein angiographic lesions in galactose-fed dogs. Arch. Ophthalmol. 2003, 121, 1745-1751. [CrossRef] [PubMed]

34. Yang, Y.; Hayden, M.R.; Sowers, S.; Bagree, S.V.; Sowers, J.R. Retinal redox stress and remodeling in cardiometabolic syndrome and diabetes. Oxid. Med. Cell. Longev. 2010, 3, 392-403. [CrossRef] [PubMed]

35. Olivares, A.M.; Althoff, K.; Chen, G.F.; Wu, S.; Morrisson, M.A.; DeAngelis, M.M.; Haider, N. Animal Models of Diabetic Retinopathy. Curr. Diab. Rep. 2017, 17, 93. [CrossRef] [PubMed]

36. Seita, M.; Noguchi, H.; Kubota, Y.; Kawamoto, H.; Nakaji, S.; Kobayashi, N.; Fujiwara, T. Development of Canine Models of Type 1 Diabetes with Partial Pancreatectomy and the Administration of Streptozotocin. Cell. Med. 2013, 6, 25-31. [CrossRef] [PubMed]

37. Hatchell, D.L.; Toth, C.A.; Barden, C.A.; Saloupis, P. Diabetic retinopathy in a cat. Exp. Eye Res. 1995, 60, 591-593. [CrossRef]

38. Chronopoulos, A.; Roy, S.; Beglova, E.; Mansfield, K.; Wachtman, L.; Roy, S. Hyperhexosemia-Induced Retinal Vascular Pathology in a Novel Primate Model of Diabetic Retinopathy. Diabetes 2015, 64, 2603-2608. [CrossRef]

39. Rajagopal, R.; Bligard, G.W.; Zhang, S.; Yin, L.; Lukasiewicz, P.; Semenkovich, C.F. Functional Deficits Precede Structural Lesions in Mice with High-Fat Diet-Induced Diabetic Retinopathy. Diabetes 2016, 65, 1072-1084. [CrossRef]

40. Buchi, E.R.; Kurosawa, A.; Tso, M.O. Retinopathy in diabetic hypertensive monkeys: A pathologic study. Graefe's Arch. Clin. Exp. Ophthalmol. 1996, 234, 388-398. [CrossRef]

41. Yoshioka, M.; Kayo, T.; Ikeda, T.; Koizumi, A. A novel locus, Mody4, distal to D7Mit189 on chromosome 7 determines early-onset NIDDM in nonobese C57BL/6 (Akita) mutant mice. Diabetes 1997, 46, 887-894. [CrossRef] [PubMed]

42. Barber, A.J.; Antonetti, D.A.; Kern, T.S.; Reiter, C.E.; Soans, R.S.; Krady, J.K.; Levison, S.W.; Gardner, T.W.; Bronson, S.K. The Ins2Akita mouse as a model of early retinal complications in diabetes. Investig. Ophthalmol. Vis. Sci. 2005, 46, 2210-2218. [CrossRef] [PubMed]

43. Wicker, L.S.; Todd, J.A.; Peterson, L.B. Genetic control of autoimmune diabetes in the NOD mouse. Annu. Rev. Immunol. 1995, 13, 179-200. [CrossRef] [PubMed]

44. Makino, S.; Kunimoto, K.; Muraoka, Y.; Mizushima, Y.; Katagiri, K.; Tochino, Y. Breeding of a non-obese, diabetic strain of mice Jikken Dobutsu 1980, 29, 1-13.

45. Hummel, K.P.; Dickie, M.M.; Coleman, D.L. Diabetes, a new mutation in the mouse. Science 1966, 153, 1127-1128. [CrossRef]

46. van Eeden, P.E.; Tee, L.B.; Lukehurst, S.; Lai, C.M.; Rakoczy, E.P.; Beazley, L.D.; Dunlop, S.A. Early vascular and neuronal changes in a VEGF transgenic mouse model of retinal neovascularization. Investig. Ophthalmol. Vis. Sci. 2006, 47, 4638-4645. [CrossRef]

47. Rakoczy, E.P.; Ali Rahman, I.S.; Binz, N.; Li, C.R.; Vagaja, N.N.; de Pinho, M.; Lai, C.M. Characterization of a mouse model of hyperglycemia and retinal neovascularization. Am. J. Pathol. 2010, 177, 2659-2670. [CrossRef] 
48. Sima, A.A.; Chakrabarti, S.; Garcia-Salinas, R.; Basu, P.K. The BB-rat-An authentic model of human diabetic retinopathy. Curr. Eye Res. 1985, 4, 1087-1092. [CrossRef]

49. Sima, A.A.; Garcia-Salinas, R.; Basu, P.K. The BB Wistar rat: An experimental model for the study of diabetic retinopathy Metabolism 1983, 32, 136-140. [CrossRef]

50. Miyamura, N.; Amemiya, T. Lens and retinal changes in the WBN/Kob rat (spontaneously diabetic strain). Electron-microscopic study. Ophthalmic. Res. 1998, 30, 221-232. [CrossRef]

51. Yokoi, N.; Hoshino, M.; Hidaka, S.; Yoshida, E.; Beppu, M.; Hoshikawa, R.; Sudo, K.; Kawada, A.; Takagi, S.; Seino, S. A Novel Rat Model of Type 2 Diabetes: The Zucker Fatty Diabetes Mellitus ZFDM Rat. J. Diabetes Res. 2013, 2013, 103731. [CrossRef] [PubMed]

52. Peterson, R.G.; Shaw, W.N.; Neel, M.A.; Little, L.A.; Eichberg, J. Zucker Diabetic Fatty Rat as a Model for Non-insulin-dependent Diabetes Mellitus. ILAR J. 1990, 32, 16-19. [CrossRef]

53. Lu, Z.Y.; Bhutto, I.A.; Amemiya, T. Retinal changes in Otsuka long-evans Tokushima Fatty rats (spontaneously diabetic rat)Possibility of a new experimental model for diabetic retinopathy. Jpn. J. Ophthalmol. 2003, 47, 28-35. [CrossRef]

54. Shinohara, M.; Masuyama, T.; Shoda, T.; Takahashi, T.; Katsuda, Y.; Komeda, K.; Kuroki, M.; Kakehashi, A.; Kanazawa, Y. A new spontaneously diabetic non-obese Torii rat strain with severe ocular complications. Int. J. Exp. Diabetes Res. 2000, 1, 89-100. [CrossRef]

55. Smith, L.E.; Wesolowski, E.; McLellan, A.; Kostyk, S.K.; D'Amato, R.; Sullivan, R.; D'Amore, P.A. Oxygen-induced retinopathy in the mouse. Investig. Ophthalmol. Vis. Sci. 1994, 35, 101-111.

56. Patz, A.; Eastham, A.; Higginbotham, D.H.; Kleh, T. Oxygen studies in retrolental fibroplasia. II. The production of the microscopic changes of retrolental fibroplasia in experimental animals. Am. J. Ophthalmol. 1953, 36, 1511-1522. [CrossRef]

57. McLeod, D.S.; Lutty, G.A. Targeting VEGF in canine oxygen-induced retinopathy-A model for human retinopathy of prematurity. Eye Brain 2016, 8, 55-65. [CrossRef]

58. Zhang, S.X.; Ma, J.X.; Sima, J.; Chen, Y.; Hu, M.S.; Ottlecz, A.; Lambrou, G.N. Genetic difference in susceptibility to the blood-retina barrier breakdown in diabetes and oxygen-induced retinopathy. Am. J. Pathol. 2005, 166, 313-321. [CrossRef]

59. Ozaki, H.; Hayashi, H.; Vinores, S.A.; Moromizato, Y.; Campochiaro, P.A.; Oshima, K. Intravitreal sustained release of VEGF causes retinal neovascularization in rabbits and breakdown of the blood-retinal barrier in rabbits and primates. Exp. Eye Res. 1997, 64, 505-517. [CrossRef]

60. Cao, R.; Jensen, L.D.; Soll, I.; Hauptmann, G.; Cao, Y. Hypoxia-induced retinal angiogenesis in zebrafish as a model to study retinopathy. PLOS ONE 2008, 3, e2748. [CrossRef]

61. van Rooijen, E.; Voest, E.E.; Logister, I.; Bussmann, J.; Korving, J.; van Eeden, F.J.; Giles, R.H.; Schulte-Merker, S. Von HippelLindau tumor suppressor mutants faithfully model pathological hypoxia-driven angiogenesis and vascular retinopathies in zebrafish. Dis. Model. Mech. 2010, 3, 343-353. [CrossRef] [PubMed]

62. Chaudhry, Z.Z.; Morris, D.L.; Moss, D.R.; Sims, E.K.; Chiong, Y.; Kono, T.; Evans-Molina, C. Streptozotocin is equally diabetogenic whether administered to fed or fasted mice. Lab. Anim. 2013, 47, 257-265. [CrossRef] [PubMed]

63. Fong, D.S.; Aiello, L.P.; Ferris, F.L., 3rd; Klein, R. Diabetic retinopathy. Diabetes Care 2004, 27, 2540-2553. [CrossRef] [PubMed]

64. Zhang, S.X.; Wang, J.J.; Gao, G.; Shao, C.; Mott, R.; Ma, J.X. Pigment epithelium-derived factor (PEDF) is an endogenous antiinflammatory factor. FASEB J. 2006, 20, 323-325. [CrossRef]

65. Kim, C.B.; D'Amore, P.A.; Connor, K.M. Revisiting the mouse model of oxygen-induced retinopathy. Eye Brain 2016, 8, 67-79. [CrossRef]

66. Vessey, K.A.; Wilkinson-Berka, J.L.; Fletcher, E.L. Characterization of retinal function and glial cell response in a mouse model of oxygen-induced retinopathy. J. Comp. Neurol. 2011, 519, 506-527. [CrossRef]

67. Downie, L.E.; Pianta, M.J.; Vingrys, A.J.; Wilkinson-Berka, J.L.; Fletcher, E.L. AT1 receptor inhibition prevents astrocyte degeneration and restores vascular growth in oxygen-induced retinopathy. Glia 2008, 56, 1076-1090. [CrossRef]

68. Shen, W.Y.; Lai, C.M.; Graham, C.E.; Binz, N.; Lai, Y.K.; Eade, J.; Guidolin, D.; Ribatti, D.; Dunlop, S.A.; Rakoczy, P.E. Longterm global retinal microvascular changes in a transgenic vascular endothelial growth factor mouse model. Diabetologia 2006, 49, 1690-1701. [CrossRef]

69. Han, Z.; Guo, J.; Conley, S.M.; Naash, M.I. Retinal angiogenesis in the Ins2(Akita) mouse model of diabetic retinopathy. Investig. Ophthalmol. Vis. Sci. 2013, 54, 574-584. [CrossRef]

70. Kim, J.H.; Kim, J.H.; Yu, Y.S.; Cho, C.S.; Kim, K.W. Blockade of angiotensin II attenuates VEGF-mediated blood-retinal barrier breakdown in diabetic retinopathy. J. Cereb. Blood Flow Metab. 2009, 29, 621-628. [CrossRef]

71. Feit-Leichman, R.A.; Kinouchi, R.; Takeda, M.; Fan, Z.; Mohr, S.; Kern, T.S.; Chen, D.F. Vascular damage in a mouse model of diabetic retinopathy: Relation to neuronal and glial changes. Investig. Ophthalmol. Vis. Sci. 2005, 46, 4281-4287. [CrossRef] [PubMed]

72. Jariyapongskul, A.; Rungjaroen, T.; Kasetsuwan, N.; Patumraj, S.; Seki, J.; Niimi, H. Long-term effects of oral vitamin C supplementation on the endothelial dysfunction in the iris microvessels of diabetic rats. Microvasc. Res. 2007, 74, 32-38. [CrossRef] [PubMed]

73. Anderson, H.R.; Stitt, A.W.; Gardiner, T.A.; Archer, D.B. Diabetic retinopathy: Morphometric analysis of basement membrane thickening of capillaries in different retinal layers within arterial and venous environments. Br. J. Ophthalmol. 1995, 79, 1120-1123. [CrossRef] 
74. Gong, C.Y.; Lu, B.; Hu, Q.W.; Ji, L.L. Streptozotocin induced diabetic retinopathy in rat and the expression of vascular endothelial growth factor and its receptor. Int. J. Ophthalmol. 2013, 6, 573-577. [CrossRef]

75. Schroder, S.; Palinski, W.; Schmid-Schonbein, G.W. Activated monocytes and granulocytes, capillary nonperfusion, and neovascularization in diabetic retinopathy. Am. J. Pathol. 1991, 139, 81-100. [PubMed]

76. Kowluru, R.A.; Tang, J.; Kern, T.S. Abnormalities of retinal metabolism in diabetes and experimental galactosemia. VII. Effect of long-term administration of antioxidants on the development of retinopathy. Diabetes 2001, 50, 1938-1942. [CrossRef]

77. Blair, N.P.; Tso, M.O.; Dodge, J.T. Pathologic studies of the blood-Retinal barrier in the spontaneously diabetic BB rat. Investig Ophthalmol. Vis. Sci. 1984, 25, 302-311.

78. Behl, Y.; Krothapalli, P.; Desta, T.; DiPiazza, A.; Roy, S.; Graves, D.T. Diabetes-enhanced tumor necrosis factor-alpha production promotes apoptosis and the loss of retinal microvascular cells in type 1 and type 2 models of diabetic retinopathy. Am. J. Pathol. 2008, 172, 1411-1418. [CrossRef]

79. Cheung, A.K.; Fung, M.K.; Lo, A.C.; Lam, T.T.; So, K.F.; Chung, S.S.; Chung, S.K. Aldose reductase deficiency prevents diabetes-induced blood-retinal barrier breakdown, apoptosis, and glial reactivation in the retina of db/db mice. Diabetes 2005, 54, 3119-3125. [CrossRef]

80. Clements, R.S., Jr.; Robison, W.G., Jr.; Cohen, M.P. Anti-glycated albumin therapy ameliorates early retinal microvascular pathology in db/db mice. J. Diabetes Complicat. 1998, 12, 28-33. [CrossRef]

81. Li, Q.; Zemel, E.; Miller, B.; Perlman, I. Early retinal damage in experimental diabetes: Electroretinographical and morphological observations. Exp. Eye Res. 2002, 74, 615-625. [CrossRef] [PubMed]

82. Shruthi, K.; Reddy, S.S.; Reddy, G.B. Ubiquitin-proteasome system and ER stress in the retina of diabetic rats. Arch. Biochem. Biophys. 2017, 627, 10-20. [CrossRef] [PubMed]

83. Park, S.H.; Park, J.W.; Park, S.J.; Kim, K.Y.; Chung, J.W.; Chun, M.H.; Oh, S.J. Apoptotic death of photoreceptors in the streptozotocin-induced diabetic rat retina. Diabetologia 2003, 46, 1260-1268. [CrossRef] [PubMed]

84. Pitale, P.M.; Saltykova, I.V.; Adu-Agyeiwaah, Y.; Calzi, S.L.; Satoh, T.; Akira, S.; Gorbatyuk, O.; Boulton, M.E.; Pardue, M.T.; Garvey, W.T.; et al. Tribbles Homolog 3 Mediates the Development and Progression of Diabetic Retinopathy. Diabetes 2021, 70, 1738-1753. [CrossRef] [PubMed]

85. Robison, W.G., Jr.; Tillis, T.N.; Laver, N.; Kinoshita, J.H. Diabetes-related histopathologies of the rat retina prevented with an aldose reductase inhibitor. Exp. Eye Res. 1990, 50, 355-366. [CrossRef]

86. Szabo, K.; Enzsoly, A.; Dekany, B.; Szabo, A.; Hajdu, R.I.; Radovits, T.; Matyas, C.; Olah, A.; Laurik, L.K.; Somfai, G.M.; et al. Histological Evaluation of Diabetic Neurodegeneration in the Retina of Zucker Diabetic Fatty (ZDF) Rats. Sci. Rep. 2017, 7, 8891. [CrossRef]

87. Downie, L.E.; Pianta, M.J.; Vingrys, A.J.; Wilkinson-Berka, J.L.; Fletcher, E.L. Neuronal and glial cell changes are determined by retinal vascularization in retinopathy of prematurity. J. Comp. Neurol. 2007, 504, 404-417. [CrossRef]

88. Liu, K.; Akula, J.D.; Falk, C.; Hansen, R.M.; Fulton, A.B. The retinal vasculature and function of the neural retina in a rat model of retinopathy of prematurity. Investig. Ophthalmol. Vis. Sci. 2006, 47, 2639-2647. [CrossRef]

89. Yang, Y.; Mao, D.; Chen, X.; Zhao, L.; Tian, Q.; Liu, C.; Zhou, B.L. Decrease in retinal neuronal cells in streptozotocin-induced diabetic mice. Mol. Vis. 2012, 18, 1411-1420.

90. Martin, P.M.; Roon, P.; Van Ells, T.K.; Ganapathy, V.; Smith, S.B. Death of retinal neurons in streptozotocin-induced diabetic mice. Investig. Ophthalmol. Vis. Sci. 2004, 45, 3330-3336. [CrossRef]

91. Sohn, E.H.; van Dijk, H.W.; Jiao, C.; Kok, P.H.; Jeong, W.; Demirkaya, N.; Garmager, A.; Wit, F.; Kucukevcilioglu, M.; van Velthoven, M.E.; et al. Retinal neurodegeneration may precede microvascular changes characteristic of diabetic retinopathy in diabetes mellitus. Proc. Natl. Acad. Sci. USA 2016, 113, E2655-E2664. [CrossRef] [PubMed]

92. Hombrebueno, J.R.; Chen, M.; Penalva, R.G.; Xu, H. Loss of synaptic connectivity, particularly in second order neurons is a key feature of diabetic retinal neuropathy in the Ins2Akita mouse. PLoS ONE 2014, 9, e97970. [CrossRef] [PubMed]

93. Yang, Q.; Xu, Y.; Xie, P.; Cheng, H.; Song, Q.; Su, T.; Yuan, S.; Liu, Q. Retinal Neurodegeneration in db/db Mice at the Early Period of Diabetes. J. Ophthalmol. 2015, 2015, 757412. [CrossRef] [PubMed]

94. Kumar, S.; Zhuo, L. Longitudinal in vivo imaging of retinal gliosis in a diabetic mouse model. Exp. Eye Res. 2010, 91, 530-536. [CrossRef]

95. Pardue, M.T.; Barnes, C.S.; Kim, M.K.; Aung, M.H.; Amarnath, R.; Olson, D.E.; Thule, P.M. Rodent Hyperglycemia-Induced Inner Retinal Deficits are Mirrored in Human Diabetes. Transl. Vis. Sci. Technol. 2014, 3, 6. [CrossRef]

96. Aung, M.H.; Kim, M.K.; Olson, D.E.; Thule, P.M.; Pardue, M.T. Early visual deficits in streptozotocin-induced diabetic long evans rats. Investig. Ophthalmol. Vis. Sci. 2013, 54, 1370-1377. [CrossRef]

97. Hancock, H.A.; Kraft, T.W. Oscillatory potential analysis and ERGs of normal and diabetic rats. Investig. Ophthalmol. Vis. Sci. 2004, 45, 1002-1008. [CrossRef]

98. Okuno, T.; Oku, H.; Sugiyama, T.; Ikeda, T. Electroretinographic study of spontaneously diabetic Torii rats. Doc. Ophthalmol. 2008, 117, 191-196. [CrossRef]

99. Sasase, T.; Ohta, T.; Masuyama, T.; Yokoi, N.; Kakehashi, A.; Shinohara, M. The spontaneously diabetic torii rat: An animal model of nonobese type 2 diabetes with severe diabetic complications. J. Diabetes Res. 2013, 2013, 976209. [CrossRef]

100. Sasaki, M.; Ozawa, Y.; Kurihara, T.; Kubota, S.; Yuki, K.; Noda, K.; Kobayashi, S.; Ishida, S.; Tsubota, K. Neurodegenerative influence of oxidative stress in the retina of a murine model of diabetes. Diabetologia 2010, 53, 971-979. [CrossRef] 
101. Moore-Dotson, J.M.; Beckman, J.J.; Mazade, R.E.; Hoon, M.; Bernstein, A.S.; Romero-Aleshire, M.J.; Brooks, H.L.; Eggers, E.D. Early Retinal Neuronal Dysfunction in Diabetic Mice: Reduced Light-Evoked Inhibition Increases Rod Pathway Signaling. Investig. Ophthalmol. Vis. Sci. 2016, 57, 1418-1430. [CrossRef] [PubMed]

102. Zheng, L.; Du, Y.; Miller, C.; Gubitosi-Klug, R.A.; Kern, T.S.; Ball, S.; Berkowitz, B.A. Critical role of inducible nitric oxide synthase in degeneration of retinal capillaries in mice with streptozotocin-induced diabetes. Diabetologia 2007, 50, 1987-1996. [CrossRef] [PubMed]

103. Bogdanov, P.; Corraliza, L.; Villena, J.A.; Carvalho, A.R.; Garcia-Arumi, J.; Ramos, D.; Ruberte, J.; Simo, R.; Hernandez, C. The $\mathrm{db} / \mathrm{db}$ mouse: A useful model for the study of diabetic retinal neurodegeneration. PLoS ONE 2014, 9, e97302. [CrossRef] [PubMed]

104. Reiter, C.E.; Wu, X.; Sandirasegarane, L.; Nakamura, M.; Gilbert, K.A.; Singh, R.S.; Fort, P.E.; Antonetti, D.A.; Gardner, T.W. Diabetes reduces basal retinal insulin receptor signaling: Reversal with systemic and local insulin. Diabetes 2006, 55, 1148-1156. [CrossRef]

105. Rajala, A.; Tanito, M.; Le, Y.Z.; Kahn, C.R.; Rajala, R.V. Loss of neuroprotective survival signal in mice lacking insulin receptor gene in rod photoreceptor cells. J. Biol. Chem. 2008, 283, 19781-19792. [CrossRef]

106. Rajala, R.V.; Wiskur, B.; Tanito, M.; Callegan, M.; Rajala, A. Diabetes reduces autophosphorylation of retinal insulin receptor and increases protein-tyrosine phosphatase-1B activity. Investig. Ophthalmol. Vis. Sci. 2009, 50, 1033-1040. [CrossRef]

107. He, K.; Lv, W.; Zhang, Q.; Wang, Y.; Tao, L.; Liu, D. Gene set enrichment analysis of pathways and transcription factors associated with diabetic retinopathy using a microarray dataset. Int. J. Mol. Med. 2015, 36, 103-112. [CrossRef]

108. Jiang, Y.; Liu, L.; Li, H.; Wang, J.M.; Steinle, J.J. Insulin Signal Transduction is Impaired in the Type 2 Diabetic Retina. J. Diabetes Clin. Res. 2020, 2, 12-15.

109. Zhu, H.; Zhang, W.; Zhao, Y.; Shu, X.; Wang, W.; Wang, D.; Yang, Y.; He, Z.; Wang, X.; Ying, Y. GSK3beta-mediated tau hyperphosphorylation triggers diabetic retinal neurodegeneration by disrupting synaptic and mitochondrial functions. Mol. Neurodegener. 2018, 13, 62. [CrossRef]

110. Ma, J.H.; Wang, J.J.; Zhang, S.X. The unfolded protein response and diabetic retinopathy. J. Diabetes Res. 2014, 2014, 160140. [CrossRef]

111. Yang, L.; Wu, L.; Wang, D.; Li, Y.; Dou, H.; Tso, M.O.; Ma, Z. Role of endoplasmic reticulum stress in the loss of retinal ganglion cells in diabetic retinopathy. Neural Regen. Res. 2013, 8, 3148-3158. [CrossRef] [PubMed]

112. Li, B.; Wang, H.S.; Li, G.G.; Zhao, M.J.; Zhao, M.H. The role of endoplasmic reticulum stress in the early stage of diabetic retinopathy. Acta Diabetol. 2011, 48, 103-111. [CrossRef] [PubMed]

113. Kim, J.; Kim, C.S.; Sohn, E.; Lee, Y.M.; Jo, K.; Kim, J.S. KIOM-79 protects AGE-induced retinal pericyte apoptosis via inhibition of NF-kappaB activation in vitro and in vivo. PLoS ONE 2012, 7, e43591. [CrossRef] [PubMed]

114. Chung, Y.R.; Choi, J.A.; Koh, J.Y.; Yoon, Y.H. Ursodeoxycholic Acid Attenuates Endoplasmic Reticulum Stress-Related Retinal Pericyte Loss in Streptozotocin-Induced Diabetic Mice. J. Diabetes Res. 2017, 2017, 1763292. [CrossRef]

115. Zhong, Y.; Li, J.; Chen, Y.; Wang, J.J.; Ratan, R.; Zhang, S.X. Activation of endoplasmic reticulum stress by hyperglycemia is essential for Muller cell-derived inflammatory cytokine production in diabetes. Diabetes 2012, 61, 492-504. [CrossRef]

116. Kondo, T.; Kahn, C.R. Altered insulin signaling in retinal tissue in diabetic states. J. Biol. Chem. 2004, 279, 37997-38006. [CrossRef]

117. Li, J.; Wang, J.J.; Yu, Q.; Wang, M.; Zhang, S.X. Endoplasmic reticulum stress is implicated in retinal inflammation and diabetic retinopathy. FEBS Lett. 2009, 583, 1521-1527. [CrossRef]

118. Wang, X.; Wang, G.; Kunte, M.; Shinde, V.; Gorbatyuk, M. Modulation of angiogenesis by genetic manipulation of ATF4 in mouse model of oxygen-induced retinopathy [corrected]. Investig. Ophthalmol. Vis. Sci. 2013, 54, 5995-6002. [CrossRef]

119. Bhatta, M.; Ma, J.H.; Wang, J.J.; Sakowski, J.; Zhang, S.X. Enhanced endoplasmic reticulum stress in bone marrow angiogenic progenitor cells in a mouse model of long-term experimental type 2 diabetes. Diabetologia 2015, 58, 2181-2190. [CrossRef]

120. Rana, T.; Shinde, V.M.; Starr, C.R.; Kruglov, A.A.; Boitet, E.R.; Kotla, P.; Zolotukhin, S.; Gross, A.K.; Gorbatyuk, M.S. An activated unfolded protein response promotes retinal degeneration and triggers an inflammatory response in the mouse retina. Cell Death Dis. 2014, 5, e1578. [CrossRef]

121. Kirwin, S.J.; Kanaly, S.T.; Linke, N.A.; Edelman, J.L. Strain-dependent increases in retinal inflammatory proteins and photoreceptor FGF-2 expression in streptozotocin-induced diabetic rats. Investig. Ophthalmol. Vis. Sci. 2009, 50, 5396-5404. [CrossRef] [PubMed]

122. Kador, P.F.; Takahashi, Y.; Wyman, M.; Ferris, F., 3rd. Diabeteslike proliferative retinal changes in galactose-fed dogs. Arch. Ophthalmol. 1995, 113, 352-354. [CrossRef] [PubMed]

123. King, J.L.; Mason, J.O., 3rd; Cartner, S.C.; Guidry, C. The influence of alloxan-induced diabetes on Muller cell contractionpromoting activities in vitreous. Investig. Ophthalmol. Vis. Sci. 2011, 52, 7485-7491. [CrossRef] [PubMed]

124. Acharya, N.K.; Qi, X.; Goldwaser, E.L.; Godsey, G.A.; Wu, H.; Kosciuk, M.C.; Freeman, T.A.; Macphee, C.H.; Wilensky, R.L.; Venkataraman, V.; et al. Retinal pathology is associated with increased blood-retina barrier permeability in a diabetic and hypercholesterolaemic pig model: Beneficial effects of the LpPLA2 inhibitor Darapladib. Diab. Vasc. Dis. Res. 2017, 14, 200-213. [CrossRef] [PubMed]

125. Kleinwort, K.J.H.; Amann, B.; Hauck, S.M.; Hirmer, S.; Blutke, A.; Renner, S.; Uhl, P.B.; Lutterberg, K.; Sekundo, W.; Wolf, E.; et al. Retinopathy with central oedema in an INS (C94Y) transgenic pig model of long-term diabetes. Diabetologia 2017, 60, 1541-1549. [CrossRef] [PubMed] 
126. Lim, R.R.; Grant, D.G.; Olver, T.D.; Padilla, J.; Czajkowski, A.M.; Schnurbusch, T.R.; Mohan, R.R.; Hainsworth, D.P.; Walters, E.M.; Chaurasia, S.S. Young Ossabaw Pigs Fed a Western Diet Exhibit Early Signs of Diabetic Retinopathy. Investig. Ophthalmol. Vis. Sci. 2018, 59, 2325-2338. [CrossRef] [PubMed]

127. Tso, M.O.; Kurosawa, A.; Benhamou, E.; Bauman, A.; Jeffrey, J.; Jonasson, O. Microangiopathic retinopathy in experimental diabetic monkeys. Trans. Am. Ophthalmol. Soc. 1988, 86, 389-421.

128. Gleeson, M.; Connaughton, V.; Arneson, L.S. Induction of hyperglycaemia in zebrafish (Danio rerio) leads to morphological changes in the retina. Acta Diabetol. 2007, 44, 157-163. [CrossRef]

129. Alvarez, Y.; Chen, K.; Reynolds, A.L.; Waghorne, N.; O'Connor, J.J.; Kennedy, B.N. Predominant cone photoreceptor dysfunction in a hyperglycaemic model of non-proliferative diabetic retinopathy. Dis. Model. Mech. 2010, 3, 236-245. [CrossRef]

130. Kim, S.Y.; Johnson, M.A.; McLeod, D.S.; Alexander, T.; Otsuji, T.; Steidl, S.M.; Hansen, B.C.; Lutty, G.A. Retinopathy in monkeys with spontaneous type 2 diabetes. Investig. Ophthalmol. Vis. Sci. 2004, 45, 4543-4553. [CrossRef]

131. Lee, Y.; Yang, J. Development of a zebrafish screening model for diabetic retinopathy induced by hyperglycemia: Reproducibility verification in animal model. Biomed. Pharmacother. 2021, 135, 111201. [CrossRef] [PubMed]

132. Millan, I.; Desco, M.D.C.; Torres-Cuevas, I.; Perez, S.; Pulido, I.; Mena-Molla, S.; Mataix, J.; Asensi, M.; Ortega, A.L. Pterostilbene Prevents Early Diabetic Retinopathy Alterations in a Rabbit Experimental Model. Nutrients 2019, 12, 82. [CrossRef] [PubMed]

133. Paik, S.G.; Michelis, M.A.; Kim, Y.T.; Shin, S. Induction of insulin-dependent diabetes by streptozotocin. Inhibition by estrogens and potentiation by androgens. Diabetes 1982, 31, 724-729. [CrossRef] [PubMed]

134. Saadane, A.; Lessieur, E.M.; Du, Y.; Liu, H.; Kern, T.S. Successful induction of diabetes in mice demonstrates no gender difference in development of early diabetic retinopathy. PLOS ONE 2020, 15, e0238727. [CrossRef] 